\title{
The loss of $\mathrm{CCR}^{+}$and $\mathrm{CD} 161^{+} \mathrm{CD}^{+}{ }^{+}$T-cell homeostasis contributes to disease progression in SIV-infected rhesus macaques
}

\author{
CS McGary ${ }^{1}$, X Alvarez $^{2}$, S Harrington ${ }^{3}$, B Cervasi ${ }^{1}$, ES Ryan ${ }^{1}$, RI Iriele ${ }^{1}$, S Paganini ${ }^{1}$, JL Harper ${ }^{1}$, \\ K Easley $^{4}$, G Silvestri ${ }^{1,5}$, AA Ansari ${ }^{5}$, M Lichterfeld ${ }^{3}$, L Micci $^{1}$ and M Paiardini ${ }^{1,5}$
}

\begin{abstract}
Although previous studies have shown that CD4 ${ }^{+}$Tcells expressing CCR 6 and CD161 are depleted from blood during HIV infection, the mechanisms underlying their loss remain unclear. In this study, we investigated how the homeostasis of $\mathrm{CCR}^{+}{ }^{+}$and $\mathrm{CD} 161^{+} \mathrm{CD} 4{ }^{+}$Tcells contributes to SIV disease progression and the mechanisms responsible for their loss from circulation. By comparing SIV infection in rhesus macaques (RMs) and natural host sooty mangabeys (SMs), we found that the loss of $\mathrm{CCR} 6{ }^{+}$and $\mathrm{CD} 161^{+} \mathrm{CD} 4{ }^{+}$Tcells from circulation is a distinguishing feature of progressive SIV infection in RMs. Furthermore, while viral infection critically contributes to the loss of CD161 ${ }^{+} \mathrm{CCR}^{-}{ }^{-} \mathrm{CD} 4^{+} \mathrm{T}$ cells, a redistribution of $\mathrm{CCR} 6{ }^{+} \mathrm{CD} 161^{-}$and $\mathrm{CCR} 6{ }^{+} \mathrm{CD} 161{ }^{+} \mathrm{CD} 4{ }^{+} \mathrm{T}$ cells from the blood to the rectal mucosa is a chief mechanism for their loss during SIV infection. Finally, we provide evidence that the accumulation of CCR ${ }^{+}{ }^{+} \mathrm{CD} 4{ }^{+} \mathrm{Tcells}$ in the mucosa is damaging to the host by demonstrating their reduction from this site following initiation of antiretroviral therapy in SIV-infected RMs and their lack of accumulation in SIV-infected SMs. These data emphasize the importance of maintaining $\mathrm{CCR}^{+}{ }^{+}$and $\mathrm{CD} 161{ }^{+} \mathrm{CD} 4^{+} \mathrm{T}$-cell homeostasis, particularly in the mucosa, to prevent disease progression during pathogenic HIV/SIV infection.
\end{abstract}

\section{INTRODUCTION}

Progressive HIV-1 infection results in both a disruption of mucosal barrier integrity ${ }^{1-3}$ as well as a massive depletion of mucosal CD $4{ }^{+}$T cells. ${ }^{4-6}$ The impact of mucosal CD $4{ }^{+}$T-cell depletion on HIV disease progression was initially unclear, as $\mathrm{CD} 4{ }^{+} \mathrm{T}$ cells were found to be lost during the acute phase of both pathogenic SIV infection of rhesus macaques (RMs) as well as in nonpathogenic SIV infection of African green monkeys and sooty mangabeys (SMs). ${ }^{7,8}$ Yet, further investigation revealed the preferential loss of T helper 17 cells (Th17) in pathogenic HIV/SIV infection of humans and RMs, respectively. ${ }^{9-13}$ Th17 cells, a subset of $\mathrm{CD}^{+} \mathrm{T}$ cells found predominantly in mucosal tissues, ${ }^{9,14}$ critically contribute to mucosal defenses through their secretion of IL-17 and IL-22, ${ }^{15}$ which cause the production of antimicrobial molecules and strengthen the intestinal barrier through the production of enterocytes and claudins. ${ }^{16-19}$ As a result, the preferential depletion of Th17 cells during HIV/SIV infection is associated with a reduction of mucosal barrier integrity and an increase in microbial translocation from the intestinal lumen into circulation, thereby leading to systemic immune activation in HIV infected individuals. ${ }^{11-13,20,21}$ Thus, the maintenance of Th17 cells has been a major goal for reducing immune activation and subsequent disease progression in HIV-infected individuals.

Several mechanisms have been proposed to contribute to the loss of Th17 cells from the mucosa during pathogenic HIV/SIV infection. First, numerous groups have demonstrated that Th17 cells are highly permissive to HIV/SIV infection ${ }^{9,22-26}$ and are primary targets of SIV infection, ${ }^{27}$ which supports their early and sustained depletion. Second, $\mathrm{CD} 103^{+}$DCs, a subset of

${ }^{1}$ Division of Microbiology and Immunology, Yerkes National Primate Research Center, Emory University, Atlanta, Georgia, USA. ${ }^{2}$ Tulane National Primate Research Center, Comparative Pathology, Tulane University School of Medicine, Covington, Louisiana, USA. ${ }^{3}$ Infectious Disease Division, Brigham and Women's Hospital, Ragon Institute of Massachusetts General Hospital, MIT and Harvard, Cambridge, Massachusetts, USA. ${ }^{4}$ Department of Biostatistics and Bioinformatics, Rollins School of Public Health, Atlanta, Georgia, USA and ${ }^{5}$ Department of Pathology and Laboratory Medicine, Emory University School of Medicine, Atlanta, Georgia, USA. Correspondence: M Paiardini (mirko.paiardini@emory.edu) 
dendritic cells that promote Th17 differentiation, ${ }^{28}$ are similarly depleted from the mucosa of SIV-infected RMs. ${ }^{18}$ Third, HIV and SIV infection results in decreased levels of IL21-producing cells and serum IL-21, a pleiotropic cytokine whose functions include the maintenance of Th17 cells. ${ }^{29-33}$ Indeed, the administration of IL-21 to SIV-infected RMs transiently increased intestinal Th17 cell frequencies and decreased systemic immune activation, even in the absence of antiretroviral therapy (ART), thus supporting the molecular link between IL-21 availability and Th17 cell homeostasis. ${ }^{12,34}$ In addition, alterations in the recruitment of $\mathrm{CD} 4{ }^{+} \mathrm{T}$ cells have been suggested to contribute to Th17 cell loss during HIV/SIV infection. $^{35}$
CCR6 is a chemokine receptor expressed on Th17 cells (although not exclusively) that governs their migration to the small intestine as a result of CCL20 (MIP-3 $\alpha$ ) production, the exclusive chemokine for CCR6. ${ }^{36-39}$ Th17 cells and their precursors also express the C-type lectin receptor CD161. ${ }^{40,41}$ CD161 is expressed on NK cells, as well as on CD8 ${ }^{+}$and CD4 ${ }^{+}$ $\mathrm{T}$ cells, where its expression is tightly associated with the expression of other Th17 markers, including CCR6, thus imprinting a gut homing potential. ${ }^{41-43}$ In HIV-infected individuals, circulating $\mathrm{CCR}^{+}$and $\mathrm{CD}^{+} 61^{+} \mathrm{CD}^{+} \mathrm{T}$ cells are lost from the blood and are unable to be restored to nearnormal levels with ART. ${ }^{2,44-46}$ However, whether the loss of these CCR6 and CD161-expressing cells from the blood reflects a
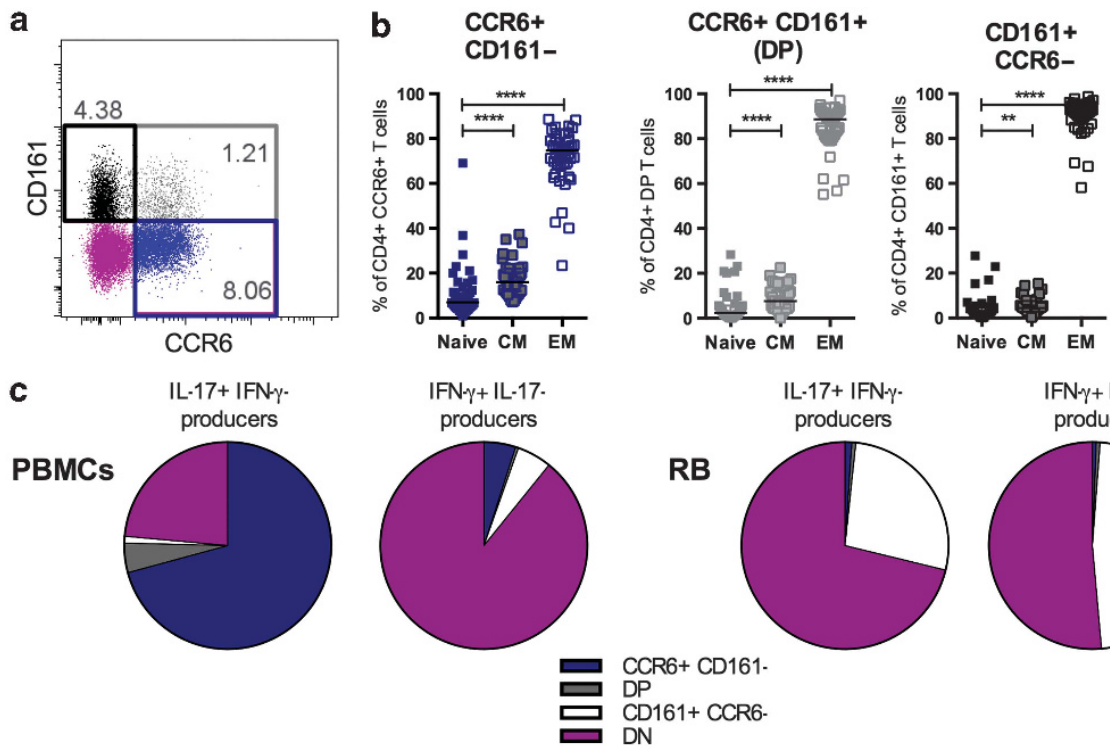

d
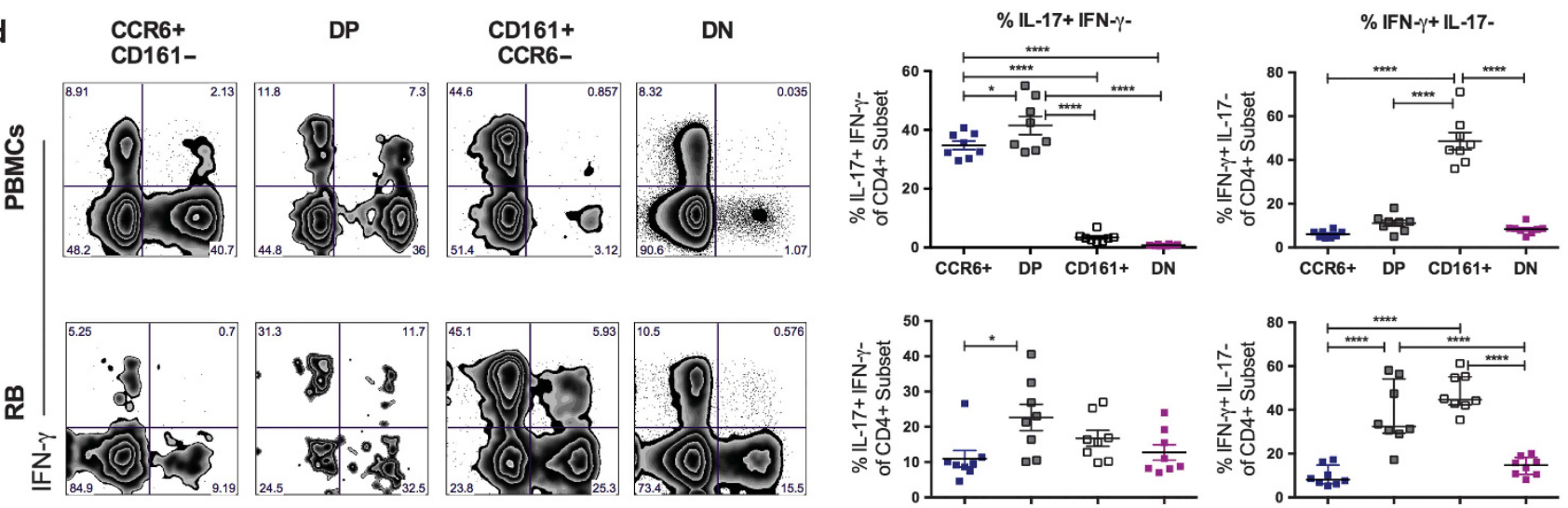

IL-17
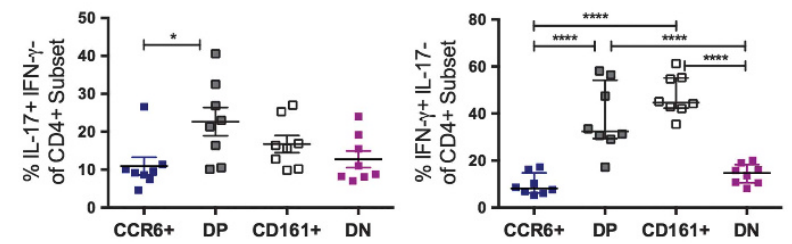

Figure $1 \mathrm{CCR}^{+}$and $\mathrm{CD} 161{ }^{+} \mathrm{CD} 4{ }^{+} \mathrm{T}$ cells contribute to interleukin (IL)-17 production in the blood and tissues. (a) Representative flow plot for the measurement of CD4 ${ }^{+} \mathrm{T}$ cells by their CCR6 and CD161 expression is shown from the blood of an uninfected rhesus macaque (RM). (b) Memory phenotypes were evaluated within CCR6 and CD161-expressing subsets in 42 healthy RMs using the following definitions: naive (CD28 ${ }^{+}$CD95 ${ }^{-}$), central memory $\left(\mathrm{CM} ; \mathrm{CD} 5^{+} \mathrm{CD}_{2} \mathrm{~L}^{+}\right)$, and effector memory $\left(\mathrm{EM} ; \mathrm{CD} 95^{+} \mathrm{CD}_{22} \mathrm{~L}^{-}\right)$. The frequencies of naïve and memory subsets are shown as a percentage of the CD4 ${ }^{+}$T-cell subsets. Medians are indicated by the horizontal bars on each graph $( \pm I Q R) .{ }^{* *} P<0.01 ;{ }^{* * * *} P<0.0001$, as determined by Mann-Whitney U-tests. (c) Peripheral blood mononuclear cells (PBMCs) or lymphocytes isolated from RB of 8 healthy RMs were stimulated for $4 \mathrm{~h}$ with PMA/Ionomycin, containing GolgiStop and Brefeldin A, in order to quantify their production of IL-17 and interferon (IFN)- $\gamma$. The average contribution by each CCR6 and CD161-expressing CD4 ${ }^{+}$T-cell subset to IL-17 and IFN- $\gamma$ production within the blood and RB are represented by the pie charts. (d) Representative flow plots are shown for the levels of IL-17 and IFN- $\gamma$ production produced by each CCR6 and CD161-expressing subset following $4 \mathrm{~h}$ PMA/Ionomycin stimulation $(n=8)$. The frequencies of IL- $17^{+}$IFN- $\gamma^{-}$as well as IFN- $\gamma^{+} \mathrm{IL}-17^{-}$producing cells within these subsets are shown for eight uninfected RMs. Averaged data are presented as the mean \pm s.e.m., and analysis of variances (ANOVAs) using Tukey's adjustment for multiple comparisons were used to compare differences between subsets. ${ }^{\star} P<0.05$; ${ }^{\star \star \star \star} P<0.0001$. 
true depletion of this subset from HIV-infected individuals is uncertain, since few studies have been able to examine their cellular dynamics in different anatomic tissues. CCL20 is secreted by mucosal epithelial cells in response to inflammatory stimuli, including cytokines (IL-1 $\alpha$ and TNF $\alpha$ ) and bacteria (Salmonella and Segmented filamentous bacteria). ${ }^{47-49}$ Therefore, progressive HIV infection, which is characterized by loss of mucosal barrier integrity and increased interaction with pro-inflammatory mediators, may lead to increased CCL20 production and consequently, increased recruitment of CCR6expressing cells to the gut mucosa. ${ }^{1,3}$ It is unclear, then, what drives the loss of CCR6 ${ }^{+}$and $\mathrm{CD} 161^{+} \mathrm{CD}^{+}{ }^{+} \mathrm{T}$ cells from the blood and how these dynamics contribute to the preferential depletion of mucosal Th17 cells during pathogenic HIV/SIV infection.

In this study, we sought to determine how the homeostasis of $\mathrm{CCR}^{+}$and $\mathrm{CD} 161^{+} \mathrm{CD} 4^{+} \mathrm{T}$ cells contributes to SIV disease progression by comparing the dynamics of these populations between a cohort of SIV-infected RMs and a cohort of naturally SIV-infected SMs. In addition, we investigated the mechanisms responsible for the loss of these cell subsets from circulation during pathogenic SIV infection. Our results indicate that $\mathrm{CCR}^{+}{ }^{+}$and $\mathrm{CD} 161^{+} \mathrm{CD} 4^{+} \mathrm{T}$ cells are only depleted from the blood during progressive SIV infection of RMs, but not during SIV infection of SMs, which supports a link between the loss of these cells and SIV disease progression. Our results also revealed that, while $\mathrm{CD} 161^{+} \mathrm{CCR}^{-}{ }^{-} \mathrm{CD} 4^{+} \mathrm{T}$ cells are depleted by viral infection across all tissues sampled, $\mathrm{CCR}^{+}{ }^{+} \mathrm{CD} 161^{-}$and $\mathrm{CCR}^{+}{ }^{+} \mathrm{CD} 161^{+} \mathrm{CD}^{+}{ }^{+} \mathrm{T}$ cells are redistributed to the gut. Altogether, these data underline the importance of maintaining $\mathrm{CCR}^{+}{ }^{+}$and $\mathrm{CD}_{161}{ }^{+} \mathrm{CD} 4{ }^{+}$T-cell homeostasis, particularly in the mucosa, to prevent HIV/SIV disease progression.

\section{RESULTS}

\section{Characterization of $\mathrm{CCR}^{+}$and ${ }^{+}$D161 ${ }^{+} \mathrm{CD}^{+}{ }^{+} \mathrm{T}$ cells in rhesus macaques}

$\mathrm{CCR}^{+}{ }^{+}$and $\mathrm{CD} 161^{+} \mathrm{CD}^{+}{ }^{+} \mathrm{T}$ cells distinguish Th17 lineage polarization and Th17 precursor cells, respectively, in humans. ${ }^{36,37,40,41}$ Therefore, we first sought to characterize the phenotypic and functional properties of circulating CCR6 and CD161-expressing CD4 ${ }^{+} \mathrm{T}$ cells in healthy RMs. CCR6 and CD161 was expressed on approximately $10.6 \pm 0.5 \%$ and $5.5 \pm 0.5 \%$ of $\mathrm{CD}^{+} \mathrm{T}$ cells in the blood, respectively (Figure 1a). Unlike previous human studies where the majority of $\mathrm{CD} 61^{+}$cells co-express CCR6, ${ }^{40}<15 \%$ of $\mathrm{CD} 161^{+} \mathrm{CD} 4{ }^{+} \mathrm{T}$ cells co-expressed CCR6, suggesting a differential expression pattern between humans and RMs (Figure 1a). However, in agreement with human literature, ${ }^{36,40}$ the majority of $\mathrm{CCR}^{+}{ }^{+} \mathrm{CD} 161^{-}, \mathrm{CD}_{161}{ }^{+} \mathrm{CCR}^{-}$, and $\mathrm{CCR}^{+}{ }^{+} \mathrm{CD} 161^{+} \mathrm{CD} 4{ }^{+} \mathrm{T}$ cells fell within the memory $\left(\mathrm{CD}^{+} 5^{+}\right)$compartment, where they were predominantly effector memory cells, defined here by the absence of CD62L expression (EM, CD95 ${ }^{+} \mathrm{CD} 6 \mathrm{~L}^{-}$; Figure 1b).

The co-expression of CCR6 and CD161 has been used with other surface markers in humans to phenotypically distinguish IL-17-producing cells (Th17) ex vivo in lieu of intracellular staining for cytokine production or the master regulator RORgt. ${ }^{36,37,40}$ Thus, we investigated the ability of these subsets to produce IL-17 following stimulation with PMA and ionomycin. Within the blood, CCR6 ${ }^{+} \mathrm{CD} 161^{-} \mathrm{CD} 4{ }^{+} \mathrm{T}$ cells were the $\mathrm{CD}^{+}{ }^{+} \mathrm{T}$-cell subset contributing the most to IL-17 production, comprising $70.8 \pm 3.0 \%$ of IL-17-producing cells (Figure 1c). However, the contribution of $\mathrm{CCR} 6^{+} \mathrm{CD} 161^{-}$ $\mathrm{CD}^{+}{ }^{+} \mathrm{T}$ cells to IL-17 production was substantially lower in the rectal mucosa (RB), where they comprised only $1.05 \pm 0.13 \%$ of IL-17-producing cells (Figure 1c). This difference likely results from a combination of factors: (i) the lower frequency of CCR6 ${ }^{+} \mathrm{CD} 161^{-} \mathrm{T}$ cells within the $\mathrm{CD} 4{ }^{+} \mathrm{T}$-cell population in the rectal mucosa; and (ii) a reduced ability of mucosal $\mathrm{CCR}^{+}{ }^{+} \mathrm{CD}_{161}{ }^{-} \mathrm{CD}^{+}{ }^{+} \mathrm{T}$ cells to produce IL-17 (RB: $10.9 \pm 2.3 \%$ vs. Peripheral blood mononuclear cells (PBMCs): $34.7 \pm 1.5 \%$; Figure 1d). $\mathrm{CCR}^{+}{ }^{+} \mathrm{CD} 161^{+}$(DP) cells contained the highest frequency of IL-17 producers, both in PBMCs $(41.5 \pm 3.1 \%)$ and in RB $(22.7 \pm 3.7 \%$; Figure 1d). Interestingly, only $5.4 \pm 1.9 \%$ of $\mathrm{CD} 161^{+} \mathrm{CCR}^{-} \mathrm{CD}^{+} \mathrm{T}$ cells produced IL17 in the blood, as compared with $16.8 \pm 2.3 \%$ in the rectal mucosa (Figure 1d). Instead, CD161 ${ }^{+} \mathrm{CCR}^{-} \mathrm{CD}^{+}{ }^{+} \mathrm{T}$ cells produced high levels of IFN- $\gamma$, in both the blood and rectal mucosa (Figure 1d). Moreover, $\mathrm{CD} 161^{+} \mathrm{CCR}^{-} \mathrm{CD}^{+}{ }^{+} \mathrm{T}$ cells contributed significantly more to IL- $17^{+} \mathrm{IFN}-\gamma^{+}$production in the rectal mucosa than the other subsets (Supplementary Figure 1 online). Thus, in RMs, the small subset of $\mathrm{CCR}^{+}{ }^{+} \mathrm{CD} 161^{+}$behaves similarly to IL-17-producing $\mathrm{CCR}^{+}{ }^{+} \mathrm{CD} 161^{+} \mathrm{CD}^{+} \mathrm{T}$ cells in humans, while $\mathrm{CD} 61^{+} \mathrm{CCR}^{-} \mathrm{CD}^{+} \mathrm{T}$ cells contribute minimally to IL-17 production, particularly in the blood.

We then examined the potential susceptibility of these CCR6 and CD161-expressing subsets to SIV infection by investigating their expression of the SIV co-receptor CCR5 and Ki-67 as a marker of T-cell activation and proliferation. Interestingly, we found that while few $\mathrm{CCR} 6{ }^{+} \mathrm{CD} 161^{-} \mathrm{CD} 44^{+} \mathrm{T}$ cells expressed CCR5 (2.66 $\pm 0.36 \%)$, CD161-expressing $\mathrm{CD}^{+}{ }^{+} \mathrm{T}$ cells contained significantly higher frequencies of CCR5 ${ }^{+}$cells, particularly among the $\mathrm{CD} 161^{+} \mathrm{CCR} 6^{-}$subset $(17.0 \%$; Figure 2a). Furthermore, $\mathrm{CCR} 6{ }^{+} \mathrm{CD} 161^{+} \mathrm{CD} 4^{+} \mathrm{T}$ cells, which had high levels of CCR ${ }^{+}$cells similar to $\mathrm{CD} 161^{+} \mathrm{CCR}^{-}$cells $(17.7 \%)$, contained the highest fraction of proliferating cells $(20.1 \%$; Figure 2b). In fact, the frequencies of proliferating $\mathrm{CD} 4{ }^{+} \mathrm{T}$ cells were significantly higher in all CCR6 and CD161-expressing T-cell subsets compared with non-expressing subsets, which is consistent with their status as effector memory cells. Taken together, the increased levels of CCR5, particularly among CD161-expressing cells, combined with the higher baseline levels of proliferating cells among all CCR6 and CD161-expressing $\mathrm{CD} 4{ }^{+} \mathrm{T}$ cells would suggest a heightened permissivity of these $\mathrm{CD} 4{ }^{+}$T-cell subsets to SIV infection when compared with nonexpressing cells.

\section{Depletion of CCR6 ${ }^{+}$and $\mathrm{CD} 161^{+} \mathrm{CD}^{+}{ }^{+} \mathrm{T}$ cells is specific to pathogenic SIV infection}

Previous studies in humans have shown that $\mathrm{CCR}^{+}$and $\mathrm{CD} 161^{+} \mathrm{CD} 4{ }^{+} \mathrm{T}$ cells are depleted in the blood of HIV-infected 

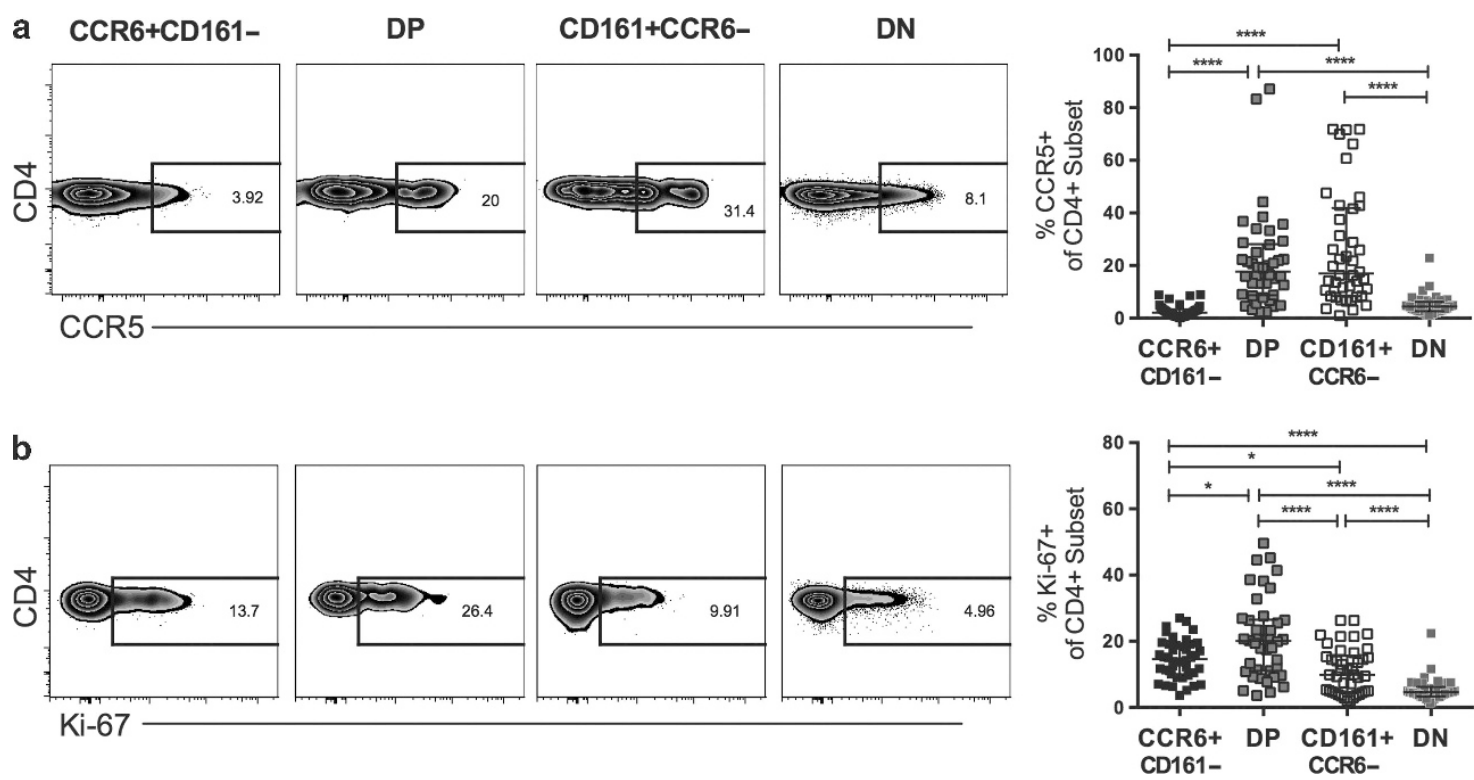

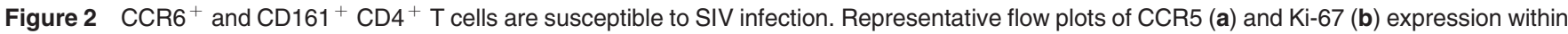
CCR6 and CD161-expressing CD4 ${ }^{+}$T cells are shown from the blood of an individual uninfected RM. The frequencies of CCR5 ${ }^{+}(\mathbf{a})$ and Ki-67 ${ }^{+}$cells $(\mathbf{b})$ within these subsets are shown for 42 uninfected RMs. Medians are indicated by the horizontal bars on each graph $( \pm \mathrm{IQR})$. ${ }^{*} P<0.05 ;{ }^{* * * \star} P<0.0001$, as determined by Mann-Whitney U-tests. A full color version of this figure is available at the Mucosal Immunology journal online. IQR, interquartile range.

individuals, even upon antiretroviral therapy (ART) initiation. $^{24,44-46}$ Whether this loss of $\mathrm{CCR}^{+}$and $\mathrm{CD}^{+} 161^{+}$ $\mathrm{CD} 4^{+} \mathrm{T}$ cells contributes to disease progression, though, has not yet been determined. To answer this question, we compared the levels of CCR6 and CD161-expressing CD4 ${ }^{+}$T-cell subsets between SIV-infected and uninfected RMs, in which SIV infection invariably progresses to AIDS, to those levels found in SIV-infected and uninfected SMs, a natural host for SIV infection that generally remain AIDS free. In the SIV-infected animals, the average durations of infection were $8.91 \pm 0.90$ years for SMs, as estimated by the date of the first SIV-positive test, and $1.02 \pm 0.12$ years for RMs. We found that $\mathrm{CCR}^{+}{ }^{+} \mathrm{CD} 161^{-}$, $\mathrm{CCR}^{+}{ }^{+} \mathrm{CD} 161^{+}$, and $\mathrm{CD} 161^{+} \mathrm{CCR}^{-}{ }^{-} \mathrm{CD} 4{ }^{+}{ }^{\mathrm{T}}$ cells were all significantly depleted from the blood of SIV-infected RMs when compared with their levels in uninfected animals (CCR6 ${ }^{+}$ $\mathrm{CD}_{161}{ }^{-}: 5.5$ vs. $9.1 \%, P=0.0002$; $\mathrm{CCR}^{+}{ }^{+} \mathrm{CD} 161^{+}: 0.06$ vs. $0.45 \%, P<0.0001$; $\mathrm{CD} 161^{+} \mathrm{CCR}^{-}: 1.18$ vs. $2.35 \%, P<0.0001$; Figure 3a). However, in the natural host SMs, we found that SIV infection did not alter the levels of these CCR6 and CD161expressing $\mathrm{CD} 4{ }^{+} \mathrm{T}$ cells, suggesting that the loss of these subsets from the blood may contribute to disease progression during pathogenic infection. Consistently, when we related the frequencies of $\mathrm{CCR}^{+} \mathrm{CD} 161^{-} \mathrm{CD}^{+} \mathrm{T}$ cells in SIVinfected RMs and SMs with their different durations of SIV infection, we confirmed that $\mathrm{CCR}^{+}{ }^{+} \mathrm{CD} 161^{-} \mathrm{CD} 4{ }^{+} \mathrm{T}$ cells decay at an approximate rate of $2.97 \%$ per year of SIV infection in RMs, while they are maintained over the duration of infection in SIV-infected SMs (Supplementary Table 1 online, slopes estimated by linear regression). Importantly, we found that the functional profiles of CCR6 and CD161-expressing CD4 ${ }^{+} \mathrm{T}$ cells, as determined by cytokine production, were comparable between SMs and RMs, with CCR6 ${ }^{+} \mathrm{CD} 161^{-} \mathrm{CD} 4{ }^{+} \mathrm{T}$ cells also comprising the highest fraction of IL-17-producing cells in the blood of SIV-uninfected SMs (74.0 $\pm 4.0 \%$; Supplementary Figure 2A). In addition, $\mathrm{CD} 161^{+} \mathrm{CCR}^{-} \mathrm{CD} 4^{+} \mathrm{T}$ cells produced the highest levels of IFN- $\gamma$ among the subsets, with $26.2 \pm 3.2 \%$ of $\mathrm{CD} 161^{+} \mathrm{CCR}^{-}{ }^{-}$cells secreting IFN- $\gamma$, on average (Supplementary Figure 2B), which together, suggests that these subsets behave similarly between the two species.

Interestingly, we found that the loss of $\mathrm{CCR}^{+}$cells was specific to $\mathrm{CD} 4{ }^{+} \mathrm{T}$ cells, as the levels of $\mathrm{CD} 8{ }^{+} \mathrm{CCR}^{+}{ }^{+} \mathrm{T}$ cells were comparable between SIV-infected and uninfected animals in both SMs and RMs (Figure 3b). Nevertheless, SIV infection was associated with a loss of $\mathrm{CD} 8{ }^{+} \mathrm{CD} 161^{+} \mathrm{T}$ cells in RMs, a finding that agrees with the well-documented loss of mucosalassociated invariant $\mathrm{T}$ (MAIT) cells in HIV-infected individuals (Figure 3c). ${ }^{50}$ These results demonstrate for the first time that the loss of CCR $6^{+}$and $\mathrm{CD} 161^{+} \mathrm{CD} 4{ }^{+} \mathrm{T}$ cells from the blood is a feature which distinguishes pathogenic from nonpathogenic SIV infection, and thus, may be a contributing factor to disease progression in SIV-infected RMs and HIVinfected individuals.

\section{$\mathrm{CCR6}^{+} \mathrm{CD} 161^{-}$and $\mathrm{CCR} 6{ }^{+} \mathrm{CD} 161^{+} \mathrm{CD}^{+}{ }^{+} \mathrm{T}$ cells accumulate in the rectal mucosa as a result of SIV infection, while $\mathrm{CD} 161^{+}{ }^{+} \mathrm{CRR}^{-} \mathrm{CD}^{+}$cells are depleted across all tissues}

While $\mathrm{CCR}^{+}{ }^{+}$and $\mathrm{CD} 161^{+} \mathrm{CD} 4{ }^{+} \mathrm{T}$ cells are lost from the blood of HIV/SIV-infected humans/RMs, ${ }^{24,44-46}$ previous studies have been unable to determine if this is due to a true depletion or if it reflects redistribution of these subsets into lymphoid tissues. Therefore, we performed a longitudinal 
a

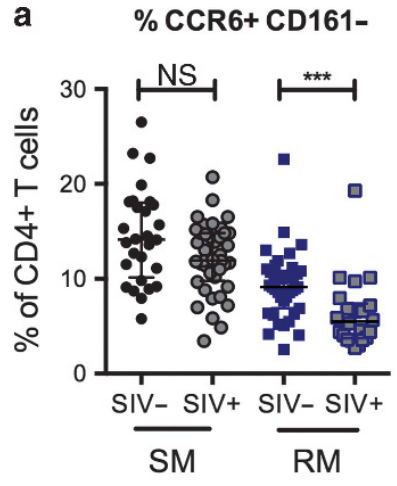

\% CCR6+ CD161+

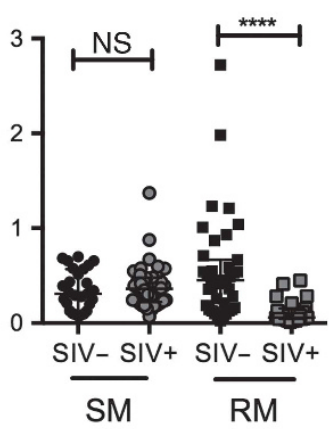

\% CD161+ CCR6-

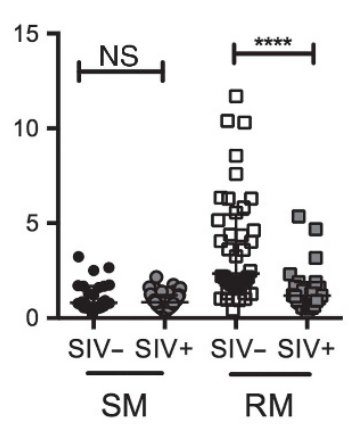

\% CCR6-CD161-

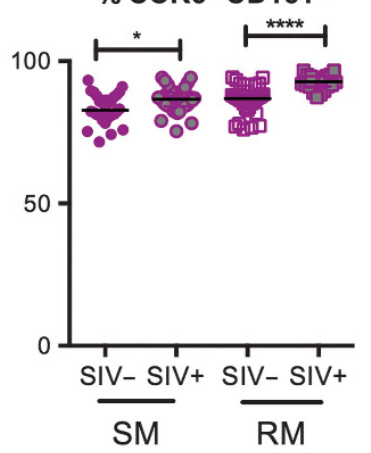

b

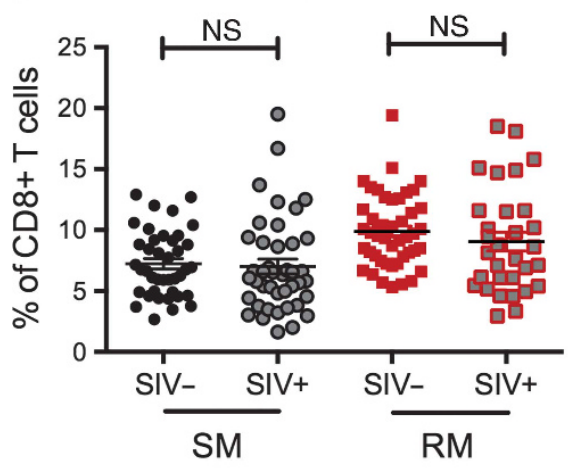

C

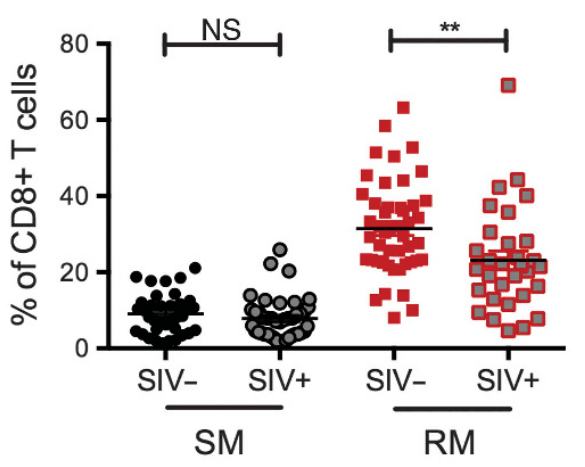

Figure 3 Only pathogenic SIV infection of rhesus macaques (RMs) results in a significant depletion of peripheral CCR6 ${ }^{+}$and CD $161^{+} \mathrm{CD} 4^{+} \mathrm{T}$ cells. (a) Frequencies of CCR6 and CD161-expressing CD4 ${ }^{+}$T-cell subsets were measured in whole blood and compared between uninfected and SIVinfected sooty mangabeys (SMs) and RMs. In the SIV-infected animals, the average lengths of infection were $8.91 \pm 0.90$ years for SMs, and $1.02 \pm 0.12$ years for RMs (see Methods). Medians are indicated by the horizontal bars on each graph ( $\pm \mathrm{IQR})$. ${ }^{\star} P<0.05 ;{ }^{* \star \star} P<0.001 ;{ }^{* \star \star \star} P<0.0001$, as determined by Mann-Whitney U-tests. (b) The frequencies of CD8 ${ }^{+}$T cells expressing CCR6 were compared between uninfected and SIV-infected SMs and RMs. (c) The percentages of $\mathrm{CD} 161^{+}$cells within $\mathrm{CD} 8^{+} \mathrm{T}$ cells were compared between healthy and SIV-infected SMs and RMs. Sample means are indicated by the horizontal bars ( \pm s.e.m.), and Mann-Whitney $U$-tests were used to compare frequencies. ${ }^{* \star} P<0.01$. IQR, interquartile range.

analysis of the frequencies of CCR6 and CD161-expressing cells within $\mathrm{CD} 4{ }^{+} \mathrm{T}$ cells in the blood, $\mathrm{RB}$, and lymph nodes (LN) of 6 SIV-infected RMs to better understand the kinetics of these cell subsets. CCR6 ${ }^{+} \mathrm{CD} 161^{-} \mathrm{CD} 4{ }^{+} \mathrm{T}$ cells were rapidly lost from the blood and LN following SIV infection, with their levels significantly lower than pre-infection levels by six and 2 weeks post infection $(P=0.0018$ and 0.0006$)$ and remaining diminished throughout chronic SIV infection (week 23, Figure 4a). Surprisingly, we found that both $\mathrm{CCR}^{+}{ }^{+} \mathrm{CD} 161^{-}$and $\mathrm{CCR}^{+}{ }^{+} \mathrm{CD} 161^{+} \mathrm{CD}^{+} \mathrm{T}$ cells accumulated in the rectal mucosa as early as 4 and 6 weeks post-SIV infection, respectively, $\quad(P=0.0280$ and $P=0.0055)$ and were maintained at significantly elevated levels as late as 23 weeks post-SIV infection $(P=0.0120$ and $P<0.0001)$. The kinetics of this increase was highly variable between animals. Nevertheless, by week 23, 5 of 6 RMs had heightened frequencies of $\mathrm{CCR}_{6}^{+} \mathrm{CD} 161^{-} \mathrm{CD} 4^{+} \mathrm{T}$ cells in the mucosa as compared with pre-infection, which was unique to this anatomic location, since the frequencies of those cells were reduced 1.9 and 4.2-fold at the same time point in blood and LN, respectively (Figure 4b). Consistent with their CCR6 expression, $\mathrm{CCR}_{6}{ }^{+} \mathrm{CD} 161^{+} \mathrm{CD} 4{ }^{+} \mathrm{T}$-cell frequencies were also increased 2.2 -fold in the mucosa at 23 weeks post-SIV infection when compared with their pre-infection frequencies, but decreased 3.1 and 4.3 -fold in the blood and LN, respectively (Figure 4b). This accumulation was distinct to CCR6expressing cells, though, and was not seen in $\mathrm{CD}_{161}{ }^{+} \mathrm{CCR}_{6}{ }^{-} \mathrm{CD} 4{ }^{+} \mathrm{T}$ cells. Instead, $\mathrm{CD} 161^{+} \mathrm{CCR}^{-}$ $\mathrm{CD}^{+}{ }^{+} \mathrm{T}$ cells were depleted across all compartments, where their decline was progressive and significant in all tissues (WB: $P<0.0001$; RB: $P=0.0016$; LN: $P=0.0026$ ) by week 23 postSIV infection (Figure $4 \mathbf{a}$ and $\mathbf{b}$ ). Of note, in agreement with the loss of CCR6 and CD161-expressing CD4 ${ }^{+} \mathrm{T}$ cells from blood and $\mathrm{LN}$, there were corresponding increases in the frequencies of CCR6 ${ }^{-} \mathrm{CD}_{161}{ }^{-}$(DN) $\mathrm{CD} 4{ }^{+}$T cells during SIV infection in these sites (Figure $\mathbf{4 a}$ and $\mathbf{b}$ ). These results suggest a different pattern of regulation between $\mathrm{CCR} 6^{+}$and $\mathrm{CD} 161^{+} \mathrm{CD} 4^{+} \mathrm{T}$ cells during SIV infection, whereby the depletion of CCR6expressing cells from the blood may result, at least in part, from their redistribution to the gut mucosa while the depletion of $\mathrm{CD}_{161}{ }^{+} \mathrm{CCR}_{6}{ }^{-} \mathrm{CD} 4{ }^{+} \mathrm{T}$ cells from the blood and tissues may result more specifically from viral infection. Indeed, this scenario is consistent with the high levels of CCR5 expression found on $\mathrm{CD} 161^{+} \mathrm{CCR}_{6}^{-} \mathrm{CD} 4^{+} \mathrm{T}$ cells in Figure 2a. 
a

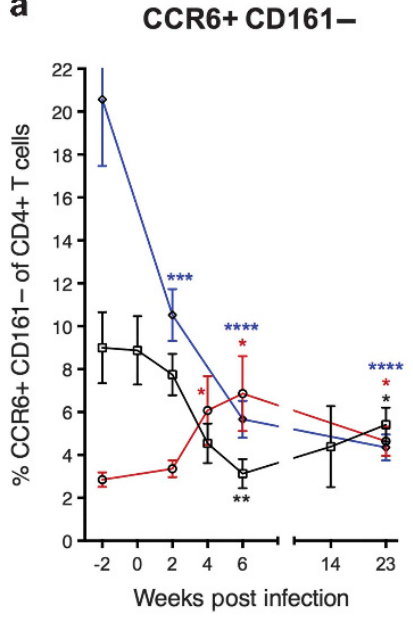

b

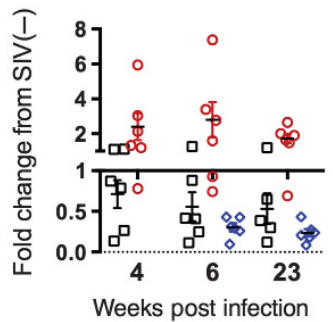

CCR6+ CD161+

(DP)

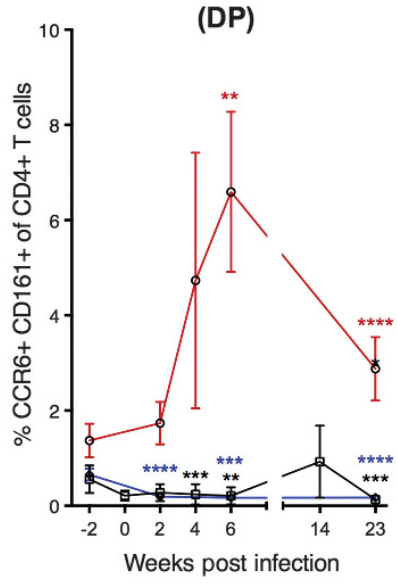

CCR6+ CD161+

(DP)

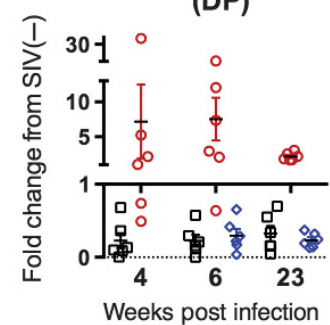

CD161+ CCR6-

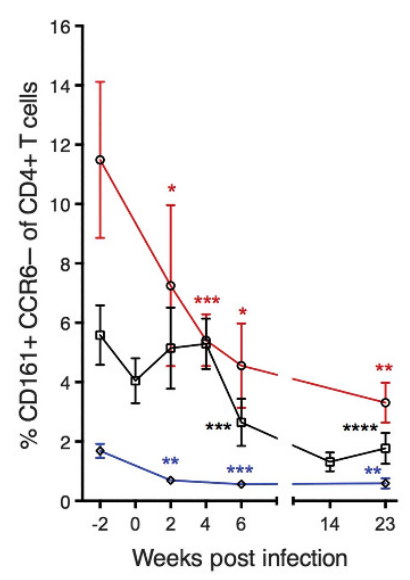

CD161+ CCR6-

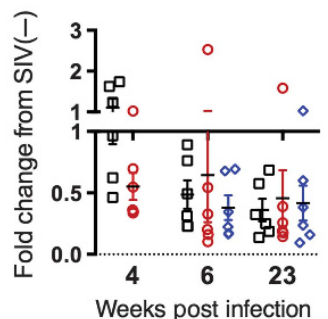

CCR6- CD161-

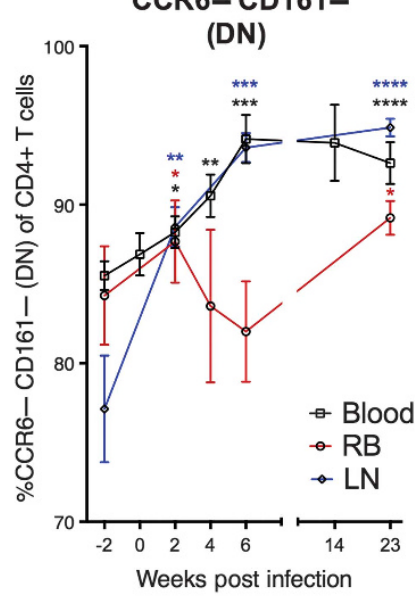

CCR6-CD161-

(DN)

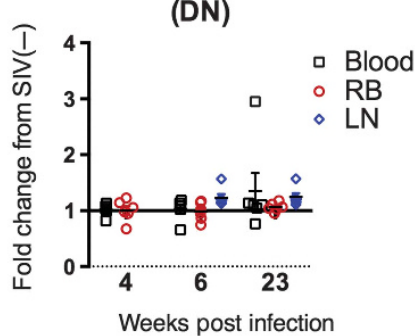

Figure $4 \mathrm{CCR}^{+} \mathrm{CD} 4^{+} \mathrm{T}$ cells accumulate in the rectal mucosa during SIV infection, but CD161 ${ }^{+} \mathrm{CCR} 6^{-} \mathrm{CD} 4^{+} \mathrm{T}$ cells are depleted in all tissues. (a) The frequencies of CCR6 and CD161-expressing T cells, expressed as a percentage of live CD4 ${ }^{+} \mathrm{T}$ cells, were measured longitudinally in the blood, rectal mucosa (RB), and lymph nodes $(\mathrm{LN})$ during the course of SIV infection for 6 RMs. Data are represented as mean \pm s.e.m. ${ }^{*} P<0.05$; ${ }^{* *} P<0.01$; ${ }^{* * *} P<0.001 ;{ }^{* * \star *} P<0.0001$, as determined by repeated-measures analyses. (b) Longitudinal assessment of the fold change of CCR6 and CD161expressing $\mathrm{CD} 4{ }^{+} \mathrm{T}$-cell subsets relative to their percentages of $\mathrm{CD} 4{ }^{+} \mathrm{T}$ cells prior to infection (Week-2) within the blood, RB, and LN. Sample means are indicated by the horizontal bars ( \pm s.e.m.).

\section{Redistribution of $\mathrm{CCR}^{+}{ }^{+} \mathrm{CD} 4^{+}{ }^{+}$T cells is concurrent with an increase in intestinal CCL20 levels}

To investigate whether an early increase in CCL20 (MIP-3 $\alpha$ ) production during acute SIV infection could be responsible for the observed accumulation of CCR6-expressing CD4 ${ }^{+} \mathrm{T}$ cells (both $\mathrm{CCR}^{+} \mathrm{CD} 161^{-}$and $\mathrm{CCR}^{+}{ }^{+} \mathrm{CD} 161^{+}$) in the gut mucosa, ${ }^{39,51,52}$ we performed in situ hybridization analysis for CCL20 longitudinally in rectal biopsy tissues of the same 6 SIVinfected RMs (Figure 5a). Levels of CCL20 in RB significantly increased during acute SIV infection (4 weeks post infection (PI); $P=0.019$; Figure 5b), which corresponded to the accumulation of CCR6-expressing $\mathrm{CD}^{+}{ }^{+} \mathrm{T}$ cells in the gut mucosa. This increase was transient, as the levels of mucosal CCL20 returned to pre-SIV baseline levels by 6 weeks post infection and chronic SIV infection (Figure 5b). Importantly, when we related the rate of bulk CCR $6{ }^{+} \mathrm{CD} 4{ }^{+}$T-cell decline from the blood to the increasing rate of bulk $\mathrm{CCR} 6{ }^{+} \mathrm{CD} 4{ }^{+}$ $\mathrm{T}$-cell levels in $\mathrm{RB}$, we found a statistically significant inverse relationship between the two populations, suggesting that the accumulation of CCR6-expressing CD4 ${ }^{+}$T cells in the mucosa is partially related to their loss from the blood (Figure 5c; $P=0.0150)$. Furthermore, the effect of increased CCL20 production was not restricted to $\mathrm{CD}^{+} \mathrm{T}$ cells but extended to $\mathrm{CCR}^{+}{ }^{+} \mathrm{CD} 8{ }^{+} \mathrm{T}$ cells, which similarly increased in the gut mucosa by 6 weeks of SIV infection (although not significantly, $P=0.098$; Figure 5d). Therefore, our data show that the redistribution of $\mathrm{CCR} 6{ }^{+} \mathrm{CD} 4{ }^{+} \mathrm{T}$ cells from the blood to the gut mucosa is directed by the increased production of CCL20 during acute infection and is partially responsible for their depletion from circulation during SIV infection of RMs.

\section{$\mathrm{CD} 161^{+} \mathrm{CCR6}^{-} \mathrm{CD}^{+}{ }^{+} \mathrm{T}$ cells harbor higher levels of SIV RNA in lymphoid tissues}

While the migration of CCR6-expressing CD ${ }^{+} \mathrm{T}$ cells to the gut mucosa affects the levels seen in circulation after SIV infection, additional mechanisms such as increased infectivity may be contributing to the loss of circulating $\mathrm{CCR}^{+}$and $\mathrm{CD} 161^{+} \mathrm{CD}^{+}{ }^{+} \mathrm{T}$ cells during chronic SIV/HIV infection. As such, we sorted memory CD $4^{+}$T cells from the PBMCs and LN of 10 chronically SIV-infected, ART-naive RMs (average length of SIV infection: $517.0 \pm 34.4$ days) based on their expression of CCR6 or CD161 and quantified the levels of cell-associated SIV DNA and RNA within each subset (Supplementary Figure 3). Although $\mathrm{CCR}^{+} \mathrm{CD} 161^{-}$cells contained the highest frequencies of infected cells in both PBMCs (median: 4560 

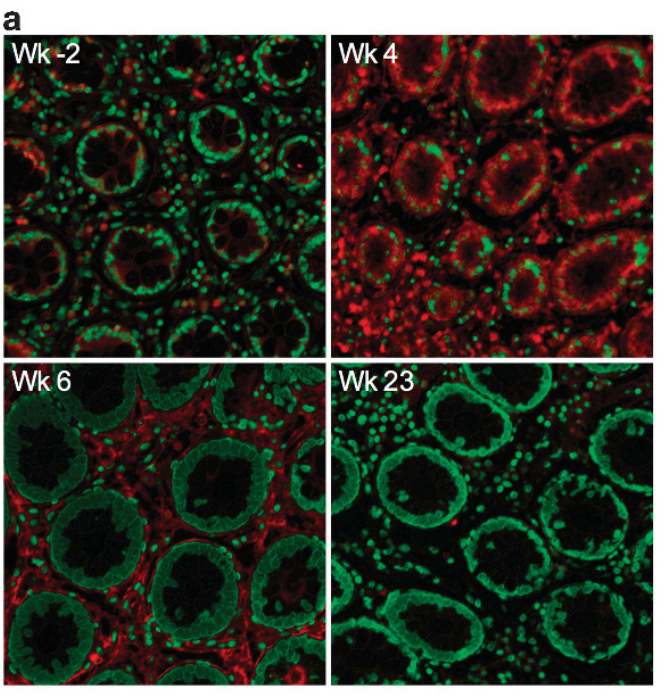

b
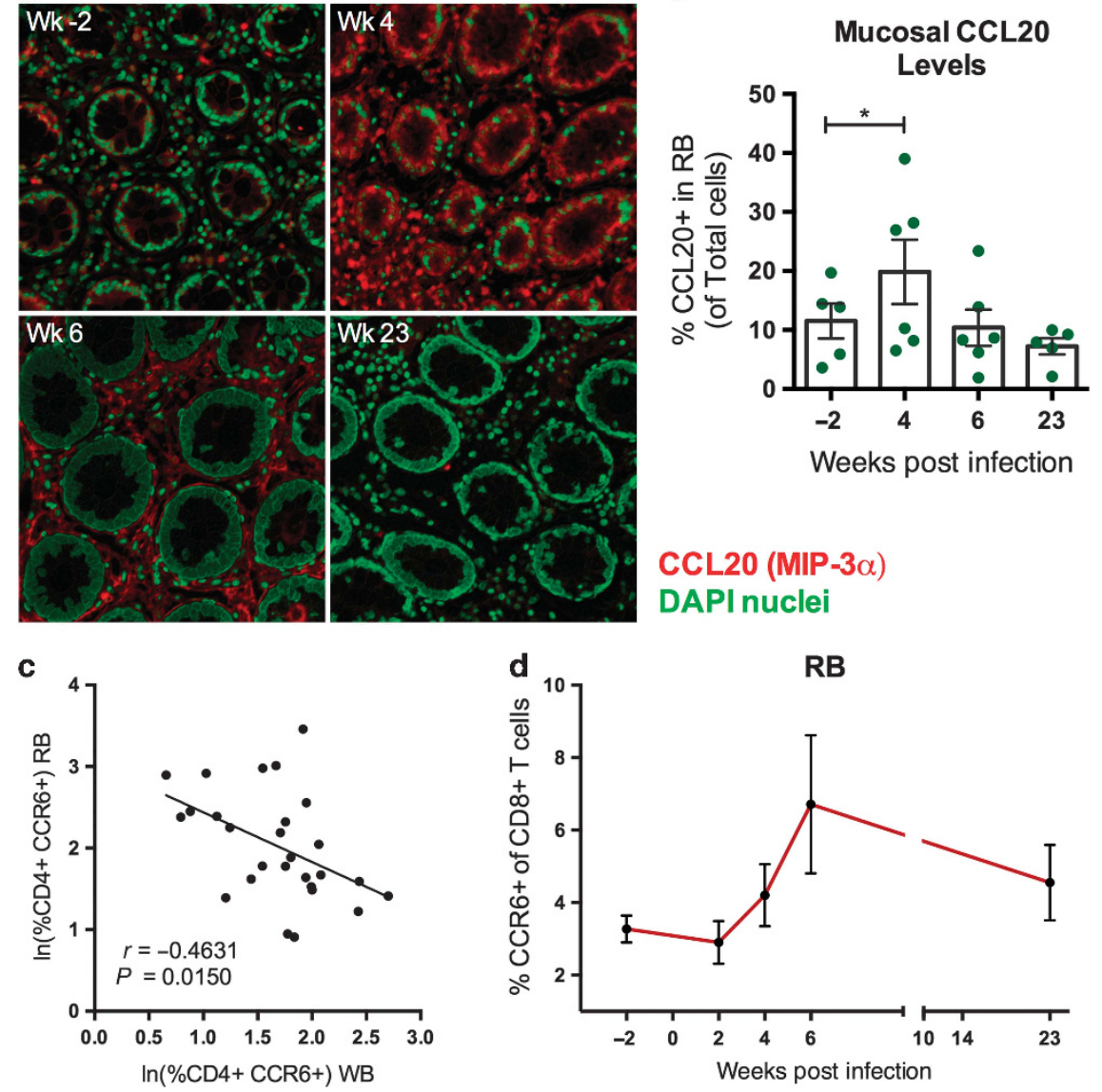

Figure 5 Increases in mucosal CCL20 production correspond to an accumulation of CCR6 ${ }^{+} \mathrm{T}$ cells during SIV infection. (a) Fixed rectal mucosal tissues underwent in situ hybridization for CCL20 (MIP-3 $\alpha$, red) and counterstaining for nuclei (DAPI, green) longitudinally during SIV infection. Representative images (40x) of each time point are shown from an individual RM (RLz8)- upper row, Weeks -2 and 4; bottom row, Weeks 6 and 23. (b) Quantitative image analysis demonstrating the fraction of total cells in the rectal mucosa that express CCL20 at 4 separate time points before and during SIV infection. Sample means are indicated by the horizontal bars ( \pm s.e.m.), and Mann-Whitney U-tests were used to compare percentages. ${ }^{\star} P<0.05$. (c) $\mathrm{CCR}_{6}{ }^{+} \mathrm{CD} 4^{+} \mathrm{T}$-cell frequencies from WB and RB were In transformed (log base e) prior to analysis by a mixed effects model. The estimated rate of linear decline for $\mathrm{CCR}^{+}{ }^{+} \mathrm{CD} 4^{+} \mathrm{T}$ cells in the RB was statistically different from zero $(P=0.0150)$, indicating a linear relationship between $\ln \left(\% \mathrm{CCR} 6^{+} \mathrm{CD}^{+}\right)$in RB and $\ln \left(\% \mathrm{CCR} 6^{+} \mathrm{CD} 4^{+}\right)$in WB. (d) The frequencies of CCR6 ${ }^{+} \mathrm{T}$ cells, expressed as a percentage of live CD8 ${ }^{+} \mathrm{T}$ cells, were measured longitudinally in the rectal mucosa (RB) during the course of SIV infection for six RMs. Data are represented as mean \pm s.e.m.

copies SIV per million cells) and LN (median: 8000 copies of SIV per million cells), neither $\mathrm{CCR}^{+}{ }^{+} \mathrm{CD} 161^{-}$nor $\mathrm{CD}_{161}{ }^{+} \mathrm{CCR}^{-}$memory ${ }^{-} \mathrm{CD} 4^{+} \mathrm{T}$ cells were enriched in SIV DNA when compared with $\mathrm{CCR}^{-} \mathrm{CD}^{-} 1^{-}(\mathrm{DN})$ memory $\mathrm{CD} 4^{+} \mathrm{T}$ cells in both the blood and LN (Figure 6a).

We also measured cell-associated SIV RNA to determine the contribution of each subset to viral production. In the PBMCs, there was a trend towards $\mathrm{CCR} 6^{+} \mathrm{CD} 161^{-} \mathrm{CD} 4^{+} \mathrm{T}$ cells expressing higher levels of SIV RNA, as demonstrated by the three representative animals shown in Figure 6b; however, the RNA expression was not significantly different among any of the sorted subsets. Nevertheless, in the LN, CD161 ${ }^{+}$CCR6 $^{-}$ memory $\mathrm{CD} 4{ }^{+} \mathrm{T}$ cells harbored significantly higher levels of SIV RNA on a per cell basis than DN memory $\mathrm{CD} 4^{+} \mathrm{T}$ cells (Figure 6c; $P=0.0078$ ). Together, these data suggest that in lymphoid tissues, $\mathrm{CD} 161^{+} \mathrm{CCR}^{-} \mathrm{CD}^{+} \mathrm{T}$ cells are highly susceptible to both viral infection and subsequent viral production. Consistent with their higher levels of cell-associated RNA, we found that $\mathrm{CD}_{161}{ }^{+} \mathrm{CCR}^{-}$ $\mathrm{CD}^{+} \mathrm{T}$ cells contained significantly higher frequencies of cells expressing the SIV co-receptor CCR5 than the other $\mathrm{CD}^{+}{ }^{+} \mathrm{T}$-cell subsets in $\mathrm{LN}$ and $\mathrm{RB}$ (Supplementary Figure 4A). $\mathrm{CD}_{161}{ }^{+} \mathrm{CCR}^{-}{ }^{-} \mathrm{CD} 4^{+} \mathrm{T}$ cells also contained the highest levels of $\mathrm{CXCR}^{+}$cells, which is in agreement with a recent report that found $\mathrm{CXCR}^{+}{ }^{+} \mathrm{T}$ follicular helper (TFH) cells harbor higher levels of virus in the LN (Supplementary Figure 4B). ${ }^{53}$ Therefore, although the redistribution of $\mathrm{CCR}^{+}{ }^{+} \mathrm{CD} 161^{-}$and $\mathrm{CCR}^{+}{ }^{+} \mathrm{CD} 161^{+}$ $\mathrm{CD}^{+} \mathrm{T}$ cells from circulation to the gut mucosa appears to be a predominant mechanism for their depletion during SIV infection, the depletion of $\mathrm{CD} 161^{+}$ $\mathrm{CCR}^{-} \mathrm{CD}^{+}{ }^{+} \mathrm{T}$ cells results more from their heightened susceptibility to SIV infection in lymphoid tissues, thus supporting their depletion from all tissue compartments following infection. 


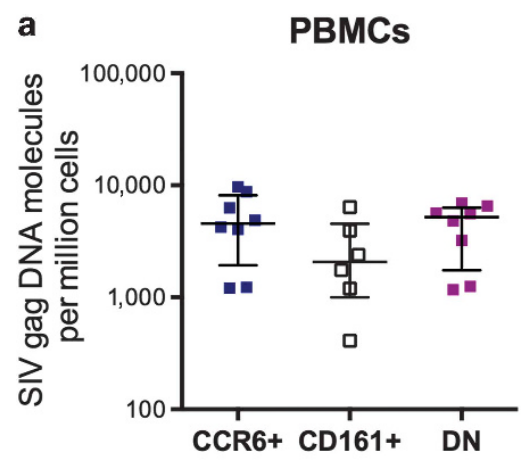

b

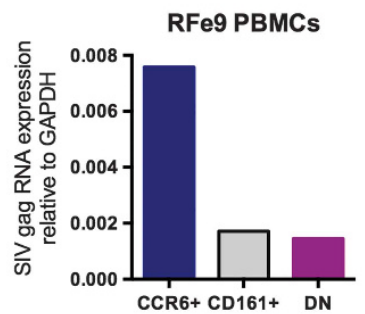

C

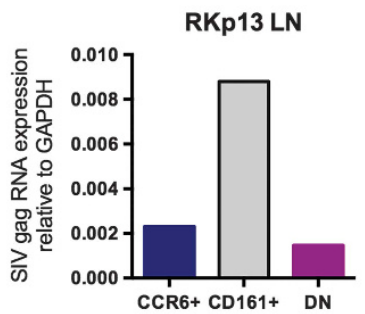

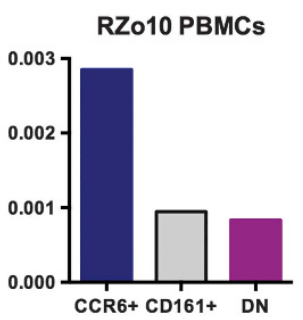

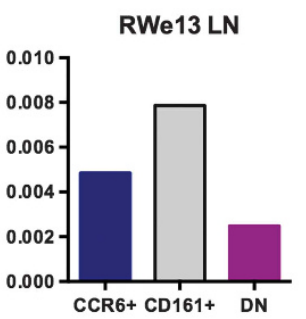

LN

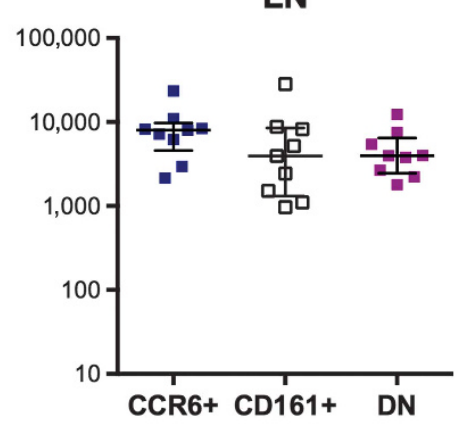

PBMCs
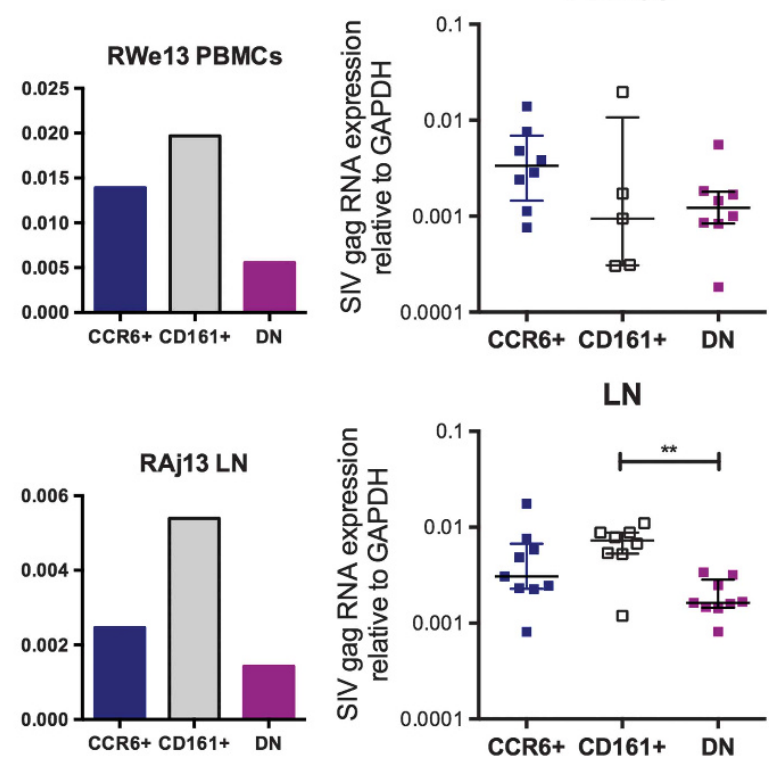

Figure $6 \mathrm{CD} 161^{+} \mathrm{CCR}^{-} \mathrm{CD} 4^{+} \mathrm{T}$ cells harbor the highest levels of SIV RNA in lymphoid tissues. (a) Levels of cell-associated SIV gag DNA were quantified from CCR6 and CD161-sorted subsets in the blood and LN of 10 SIV-infected RMs. Representative SIV RNA levels in the peripheral blood mononuclear cells (PBMCs) (b) and LN (c) for three RMs during chronic SIV infection. Cumulative data for SIV RNA levels in the CCR6 and CD161 memory CD4 ${ }^{+} \mathrm{T}$-cell subsets is shown in the scatter plots. DNA and RNA measurements were excluded for samples in which $<15,000$ cells were sorted, due to assay sensitivity limitations; two additional data points were excluded due to technical error. Medians are indicated by the horizontal bars on each graph $( \pm I Q R) .{ }^{* *} P<0.01$, as determined by Mann-Whitney $U$-tests. IQR, interquartile range.

\section{$\mathrm{CCR6}^{+} \mathrm{CD}^{\mathrm{C}} 161^{-}$and $\mathrm{CCR} 6{ }^{+} \mathrm{CD} 161^{+} \mathrm{CD}^{+}{ }^{+} \mathrm{T}$ cells are more prone to apoptosis}

Since there was no clear preference for viral infection in $\mathrm{CCR}^{+}{ }^{+} \mathrm{CD} 161^{-} \mathrm{CD} 4{ }^{+} \mathrm{T}$ cells, we also wanted to investigate if an increased susceptibility to apoptosis may contribute to the loss of these $\mathrm{CD} 4{ }^{+} \mathrm{T}$ cells from the blood during SIV infection. To do this, we evaluated apoptosis by measuring Annexin V binding in combination with Live/Dead free amine staining in PBMCs from eight healthy RMs under two different experimental conditions: (1) ex vivo, or immediately following PBMC isolation; and (2) following a $24 \mathrm{~h}$ incubation in the absence of additional stimulation (spontaneous apoptosis). We found that, at baseline, only CCR6 ${ }^{+} \mathrm{CD} 161^{+}(\mathrm{DP}) \mathrm{CD} 4^{+} \mathrm{T}$ cells had significantly elevated apoptosis levels when compared with the other $\mathrm{CD} 4{ }^{+}$T-cell subsets $(P<0.0001$, Figure 7a). However, following $24 \mathrm{~h}$ of culture, the levels of spontaneous apoptosis significantly increased in the CCR6 ${ }^{+} \mathrm{CD} 161^{-} \mathrm{CD} 4{ }^{+}$T-cell subset, with $28.6 \pm 1.8 \%$ positive for both Annexin V and Live/
Dead staining (Figure 7b) compared with only $3.20 \pm 0.53 \%$ at baseline (Figure 7a). Levels of spontaneous apoptosis in these $\mathrm{CCR}^{+}{ }^{+} \mathrm{CD} 161^{-} \mathrm{CD} 4{ }^{+} \mathrm{T}$ cells were comparable to DP levels, suggesting that $\mathrm{CCR}^{+}{ }^{+} \mathrm{CD} 4^{+} \mathrm{T}$ cells are more prone to apoptosis. Thus, in addition to migrating to the mucosa during SIV infection, increased susceptibility to apoptosis may contribute to the preferential loss of CCR6 ${ }^{+} \mathrm{CD} 4^{+} \mathrm{T}$ cells from circulation during chronic HIV/SIV infection.

\section{$\mathrm{CCR6}^{+} \mathrm{CD}^{-161^{-}} \mathrm{CD}^{+}{ }^{-} \mathrm{T}$-cell relocalization is damaging to the host}

Previous studies have reported a loss of Th17 cells from the mucosa following pathogenic HIV/SIV infection. ${ }^{9,12}$ Whether the increase in CCR6-expressing $\mathrm{CD} 4^{+}{ }^{+} \mathrm{T}$ cells in $\mathrm{RB}$, then, is beneficial to the host in promoting Th17 reconstitution or detrimental by recruiting potential viral targets has yet to be determined. To assess this, we investigated if suppressive ART restored CCR6 ${ }^{+} \mathrm{CD} 161^{-} \mathrm{CD} 4{ }^{+}$T-cell levels in the mucosa to 
a Exvivo

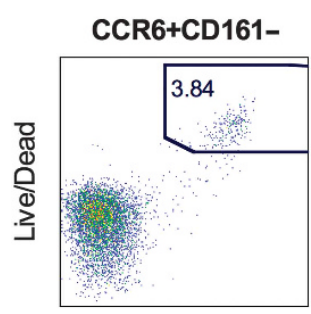

Annexin V

b

24h culture

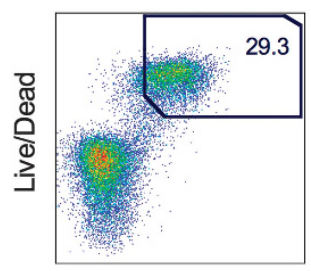

Annexin V

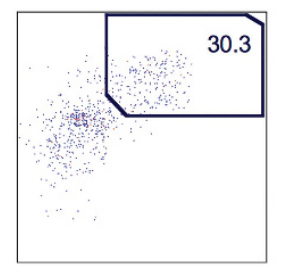

30.
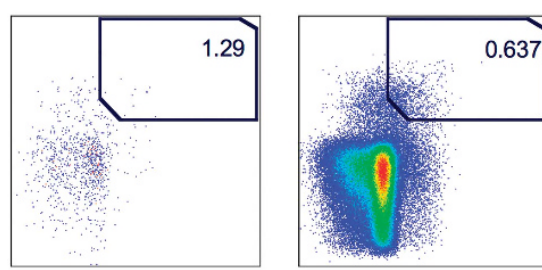

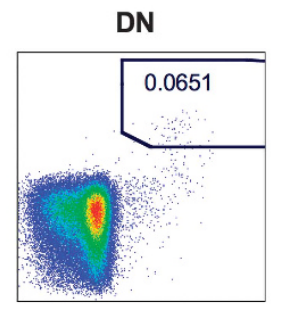

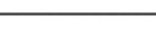

Ex vivo

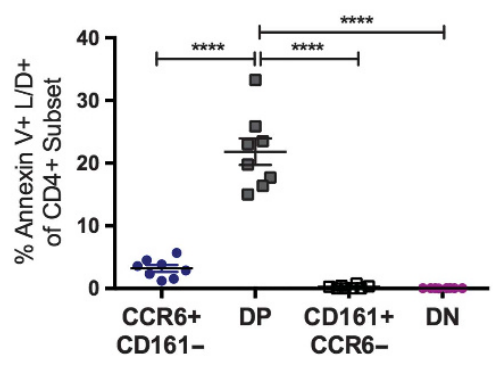

24h culture

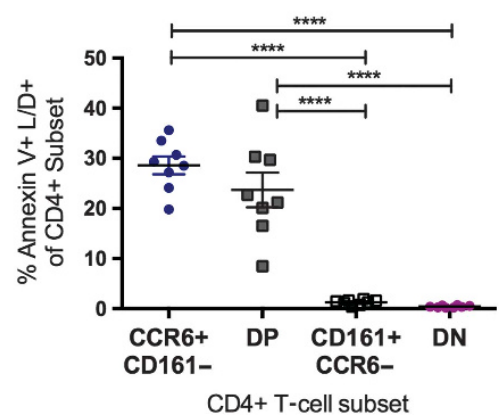

Figure $7 \mathrm{CCR}^{+}{ }^{\mathrm{CD} 161^{-}}$and $\mathrm{CCR} 6{ }^{+} \mathrm{CD} 161^{+} \mathrm{CD} 4^{+} \mathrm{T}$ cells are more susceptible to cell death than $\mathrm{CD} 4{ }^{+} \mathrm{T}$ cells not expressing CCR6. (a) Peripheral blood mononuclear cells (PBMCs) from 8 healthy RMs were stained ex vivo with Annexin $V$ and Live/Dead; a representative flow plot within each of the CCR6 and CD161-expressing CD4 ${ }^{+}$T-cell subsets is shown. The frequencies of AnnexinV ${ }^{+}$Live/Dead $^{+}$(Dead) cells within these subsets are shown for the 8 uninfected RMs. (b) Isolated peripheral blood mononuclear cells (PBMCs) were cultured for $24 \mathrm{~h}$ in the presence of complete RPMI media alone, prior to staining for cell death; representative flow plots within each of the CCR6 and CD161-expressing CD4 ${ }^{+} \mathrm{T}$-cell subsets are shown. The frequencies of AnnexinV ${ }^{+}$Live/Dead $^{+}$cells within these subsets are shown for the 8 uninfected RMs. Averaged data are presented as the mean \pm s.e.m., and analysis of variances (ANOVAs) using Tukey's adjustment for multiple comparisons were used to compare differences between subsets. ${ }^{* * \star *} P<0.0001$.

pre-infection levels in 6 ART-treated, SIV-infected RMs. Even when started during chronic SIV infection (ranging from 23 to 42 weeks of infection), ART was able to reduce $\mathrm{CCR}^{+}{ }^{+} \mathrm{CD} 161^{-} \mathrm{CD} 4{ }^{+} \mathrm{T}$-cell frequencies in $\mathrm{RB}$ within 4 weeks of therapy $(P=0.0047$, Figure 8a), and to levels comparable to those found in uninfected RMs (Figure 8b). In contrast, the effect of this short ART treatment on $\mathrm{CD} 161{ }^{+} \mathrm{CCR}^{-}{ }^{-} \mathrm{CD} 4{ }^{+}$T-cell frequencies was less pronounced, as two months of ART was unable to significantly increase the circulating levels of this subset (Supplementary Figure 5A and $\mathbf{B}$ ). However, ART was able to restore mucosal CD161 ${ }^{+} \mathrm{CCR}^{-}$levels to pre-infection frequencies (Supplementary Figure 5A and B). These results suggest that the migration of CCR6 ${ }^{+} \mathrm{CD}_{161}{ }^{-} \mathrm{CD} 4^{+}$T cells to the mucosa is a feature of disease progression.

Given these results, we hypothesized that $\mathrm{CCR} 6{ }^{+} \mathrm{CD} 161^{-}$ $\mathrm{CD}^{+}{ }^{+} \mathrm{T}$ cells would not accumulate in the RB of naturally SIVinfected SMs. Therefore, we compared the levels of CCR6 and CD161-expressing CD4 ${ }^{+}$T-cell subsets in RB between SIVinfected and uninfected SMs. In contrast to RMs, the frequencies of $\mathrm{CCR} 6{ }^{+} \mathrm{CD} 161^{-} \mathrm{CD} 4^{+} \mathrm{T}$ cells in $\mathrm{RB}$ were remarkably similar between SIV-infected and uninfected SMs (Figure 8c). In addition, the fraction of $\mathrm{CCR} 6{ }^{+} \mathrm{CD} 161^{+}$ $\mathrm{CD}^{+}{ }^{+} \mathrm{T}$ cells significantly decreased in RB of SIV-infected SMs compared with uninfected animals $(P=0.0049$, Figure 8c). To further confirm the association of $\mathrm{CCR} 6{ }^{+} \mathrm{CD} 161^{-} \mathrm{CD} 4{ }^{+}$ $\mathrm{T}$-cell accumulation in $\mathrm{RB}$ with damage to the host, we examined the relationship between frequencies of $\mathrm{CCR}^{+}{ }^{+} \mathrm{CD} 161^{-} \mathrm{CD} 4{ }^{+} \mathrm{T}$ cells and immunologic and virologic measures of disease progression in SIV-infected RMs. We found that the levels of CCR6 ${ }^{+} \mathrm{CD} 161^{-} \mathrm{CD} 4{ }^{+} \mathrm{T}$ cells in RB at week 23 PI were inversely related to the absolute levels of $\mathrm{CD} 4^{+} \mathrm{T}$ cells in the blood of untreated RMs at the same time point $(r=-0.8286, P=0.0583$; Figure 8d). Similarly, the frequencies of CCR $6^{+} \mathrm{CD} 161^{-} \mathrm{CD} 4{ }^{+} \mathrm{T}$ cells in the blood at week 6 PI were negatively associated with plasma viral load at the same time point $(r=-1.000, P=0.0167$; Figure 8e). Thus, these findings suggest that the migration of $\mathrm{CCR}^{+}{ }^{+} \mathrm{CD} 161^{-} \mathrm{CD}^{+} \mathrm{T}$ cells from circulation into the mucosal tract promotes immune dysfunction, may contribute to damage to the host, and ultimately advances disease progression.

\section{DISCUSSION}

The loss of mucosal CD4 ${ }^{+}$T-cell homeostasis is one of the earliest manifestations of progressive HIV infection and has been linked to microbial translocation, systemic immune activation, and ultimately, disease progression in untreated, HIV-infected individuals. ${ }^{1,254}$ Concomitant with this disruption of mucosal immunity is the loss of gut homing CCR ${ }^{+}$and 
a
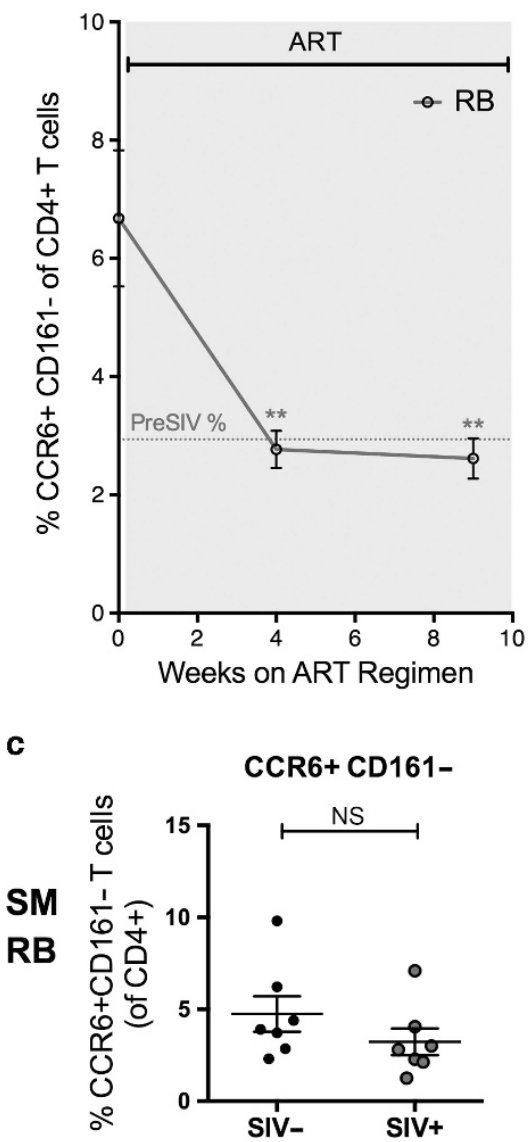

d

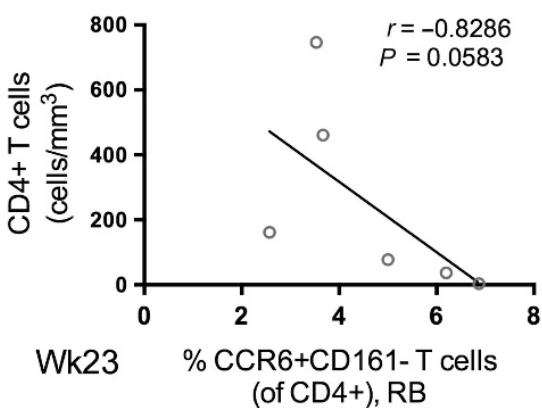

b

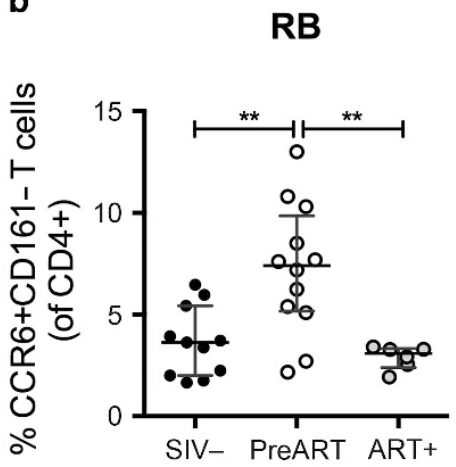

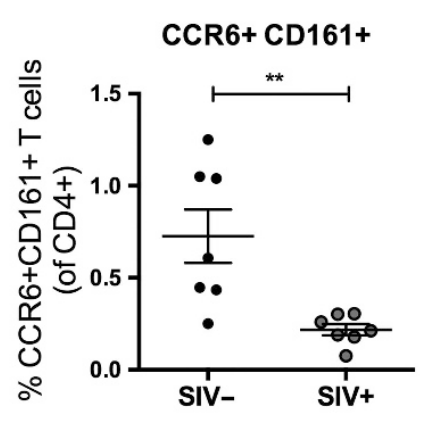

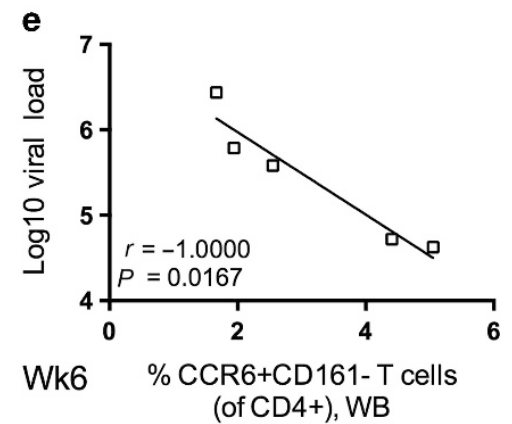

Figure 8 Increased CCR6 ${ }^{+} \mathrm{CD} 161^{-} \mathrm{CD} 4{ }^{+}$T-cell levels in the mucosa are associated with SIV disease progression. (a) The frequencies of $\mathrm{CCR}^{+}{ }^{+} \mathrm{CD} 161^{-} \mathrm{T}$ cells, expressed as a percentage of live CD4 ${ }^{+} \mathrm{T}$ cells, were measured longitudinally in RB during antiretroviral therapy (ART) administration in 6 SIV-infected RMs. Data are represented as mean \pm s.e.m. ${ }^{* \star} P<0.01$, as determined by repeated-measures analyses. The shaded area represents ART; the dotted red line indicates the baseline levels of CCR6 ${ }^{+} \mathrm{CD} 161^{-} \mathrm{CD} 4{ }^{+} \mathrm{T}$ cells in the RB of SIV-uninfected historical RM controls. (b) Cross-sectional analysis of CCR6 ${ }^{+} \mathrm{CD} 161^{+} \mathrm{CD} 4{ }^{+}$T cells in RB of uninfected $(n=12)$, untreated (PreART; $\left.n=14\right)$, and ART-suppressed $(n=8)$ SIV-infected RMs. Medians are indicated by the horizontal bars on each graph ( \pm IQR). ${ }^{\star *} P<0.01$, as determined by Mann-Whitney U-tests. (c) Frequencies of $\mathrm{CCR} 6{ }^{+} \mathrm{CD} 161^{-}$and $\mathrm{CCR} 6{ }^{+} \mathrm{CD} 161^{+} \mathrm{CD} 4^{+} \mathrm{T}$-cell subsets were measured in RB and compared between uninfected and SIV-infected sooty mangabeys (SMs). Sample means are indicated by the horizontal bars ( \pm s.e.m.). ${ }^{* \star} P<0.01$, as determined by unpaired $t$ tests. (d) The correlation between the percentage of mucosal CCR6 ${ }^{+} \mathrm{CD} 161^{-} \mathrm{CD} 4^{+}$T cells and absolute CD4 ${ }^{+}$T-cell counts are shown for SIV-infected RMs $(n=6)$ at week 23 post infection. (e) The correlation between the percentage of CCR6 ${ }^{+} \mathrm{CD} 161^{-} \mathrm{CD} 4^{+} \mathrm{T}$ cells in the blood and viral load, expressed following log transformation, are shown for SIV-infected RMs $(n=6)$ at week 6 post infection. Statistical analyses were performed using Spearman rank correlation tests. A full color version of this figure is available at the Mucosal Immunology journal online. IQR, interquartile range.

$\mathrm{CD} 61^{+} \mathrm{CD} 4^{+} \mathrm{T}$ cells from the periphery of untreated HIVinfected individuals. ${ }^{24,44-46}$ These cell subsets are known to migrate toward the gut mucosa in response to CCL20 production, which is elevated in the presence of pro-inflammatory stimuli and bacteria. ${ }^{47-49,55}$ Our findings revealed that the redistribution of $\mathrm{CCR} 6{ }^{+} \mathrm{CD} 161^{-}$and $\mathrm{CCR}^{+}{ }^{+} \mathrm{CD} 161^{+} \mathrm{CD} 4{ }^{+} \mathrm{T}$ cells to the gut mucosa, largely driven by the acute production of CCL20, is a key mechanism of 
this cell subset's depletion from the blood and lymph node. In addition, our data demonstrate that the relocalization of $\mathrm{CCR}^{+}{ }^{+} \mathrm{CD} 161^{-} \mathrm{CD} 4{ }^{+} \mathrm{T}$ cells to the gut is damaging to the host, as accumulation is not seen in SIV-infected SMs (Figure 8c) and is reversed in RMs by effective ART (Figure 8a). In contrast, $\mathrm{CD}_{161}{ }^{+} \mathrm{CCR}^{-} \mathrm{CD}^{+} \mathrm{T}$ cells were depleted from all anatomic sites accessed (blood, RB, and $\mathrm{LN}$ ), and this subset harbored high levels of SIV RNA, particularly in the LN; therefore, we hypothesize that these cells are depleted from multiple tissue sites as a result of viral infection. Despite these distinct mechanisms, the differential loss of both $\mathrm{CCR}^{+}$and $\mathrm{CD} 161^{+} \mathrm{CD}^{+}{ }^{+} \mathrm{T}$ cells between pathogenic and nonpathogenic SIV infections supports their depletion from the blood as a distinguishing feature of HIV/SIV disease progression.

Although previous studies have reported the loss of CCR6 ${ }^{+}$ $\mathrm{CD} 4^{+} \mathrm{T}$ cells from the blood of HIV-infected individuals and their incomplete restoration during ART, few studies have been able to monitor their kinetics longitudinally to define the impact of HIV infection on subset frequencies. ${ }^{24,44}$ Using the RM model of SIV infection, we were able to relate the loss of $\mathrm{CCR}^{+}{ }^{+} \mathrm{CD} 161^{-}$and CCR6 ${ }^{+} \mathrm{CD} 161^{+} \mathrm{CD} 4{ }^{+} \mathrm{T}$ cells from the blood with their accumulation in gut mucosal tissues. The recruitment of CCR6-expressing $\mathrm{CD} 4^{+} \mathrm{T}$ cells to the gut mucosa during untreated SIV infection is not unexpected, since breaches in the intestinal epithelial layer and microbial translocation are well-documented consequences of pathogenic HIV/SIV infection and previous studies have found increased CCL20 levels both in HIV-infected individuals and SIV-infected RMs. ${ }^{51,56}$ Consistent with our findings, Loiseau et al. recently described an inverse relationship between $\mathrm{CCR}^{+}{ }^{+} \mathrm{CD} 4{ }^{+} \mathrm{T}$-cell frequencies in the blood and mucosal tissues of ART-treated, HIV-infected individuals, confirming that the trafficking between these two tissue compartments occurs at all stages of HIV/SIV infection, not simply during active viral replication. ${ }^{45}$ Interestingly, our data did not support preferential viral infection as a predominant mechanism of $\mathrm{CCR}^{+}{ }^{+} \mathrm{CD} 161^{-} \mathrm{CD}^{+}{ }^{+} \mathrm{T}$-cell loss from the blood. CCR6 ${ }^{+}$ $\mathrm{CD} 161^{-} \mathrm{CD}^{+}{ }^{+} \mathrm{T}$ cells harbored similar levels of SIV to other $\mathrm{CD}^{+}{ }^{+} \mathrm{T}$-cell subsets in the blood and $\mathrm{LN}$, which differs from previous studies that demonstrated higher levels of integrated HIV DNA in $\mathrm{CCR} 6{ }^{+} \mathrm{CD} 4^{+} \mathrm{T}$ cells, when compared with CCR6 $^{-}$cells, in viremic ART-naïve humans. ${ }^{24}$ This discrepancy may arise from differences in viral DNA quantification, since measuring total cell-associated SIV DNA, as we did, may dilute the enrichment of integrated SIV DNA in $\mathrm{CCR} 6{ }^{+} \mathrm{CD} 4^{+}$ $\mathrm{T}$ cells. In addition, due to limited cell subset numbers in the rectal mucosa (resulting from an overall $\mathrm{CD} 4{ }^{+} \mathrm{T}$-cell depletion), we were unable to quantify levels of viral infection in $\mathrm{CCR}^{+}{ }^{+} \mathrm{CD} 161^{-} \mathrm{CD} 4{ }^{+} \mathrm{T}$ cells in the gut. However, the finding that $\mathrm{CCR} 6{ }^{+} \mathrm{CD} 161^{-} \mathrm{CD} 4{ }^{+} \mathrm{T}$ cells are maintained at an elevated frequency in the gut mucosa supports a mechanism where their loss from the blood during SIV infection is primarily a result of their migration to the gut mucosa as opposed to their distinct susceptibility to viral infection. In addition to their redistribution throughout the body, our data also support an increased susceptibility of $\mathrm{CCR} 6^{+} \mathrm{CD} 161^{-}$ and CCR $6{ }^{+} \mathrm{CD} 161^{+} \mathrm{CD} 4^{+} \mathrm{T}$ cells to apoptosis (Figure 7), which is an additional mechanism contributing to their loss from the blood during HIV/SIV infection.

In our study, the elevated frequencies of CCR $6{ }^{+} \mathrm{CD} 161^{-}$ $\mathrm{CD} 4^{+} \mathrm{T}$ cells in the gut mucosa following SIV infection were diminished upon ART administration (Figure 8a). In agreement with these results, a recent study found reduced production of CCL20 by enterocytes of the small intestine in ART-treated, HIV-infected individuals when compared with uninfected individuals, resulting in reduced $\mathrm{CCR} 6{ }^{+} \mathrm{CD} 4^{+}$ T-cell frequencies in the gut. ${ }^{45}$ Furthermore, we found that SIVinfected SMs maintain comparable or lower frequencies of $\mathrm{CCR}^{+}{ }^{+} \mathrm{CD} 161^{-}$and $\mathrm{CCR} 6{ }^{+} \mathrm{CD} 161^{+} \mathrm{CD}^{+}{ }^{+} \mathrm{T}$ cells, respectively, in the mucosa (Figure 8c), which strengthens our model in which redistribution of $\mathrm{CCR} 6{ }^{+} \mathrm{CD} 4{ }^{+} \mathrm{T}$ cells to the mucosa is ultimately damaging to the host. The damage that accompanies $\mathrm{CCR}^{+}{ }^{+} \mathrm{CD} 161^{-}$and $\mathrm{CCR}^{+}{ }^{+} \mathrm{CD} 161^{+}$ $\left(\mathrm{CCR}^{+}\right) \mathrm{CD}^{+}{ }^{+}$T-cell accumulation in the mucosa may result from a number of mechanisms. First, recruiting $\mathrm{CCR}^{+}{ }^{+} \mathrm{CD} 4{ }^{+} \mathrm{T}$ cells to the mucosa may increase the inflammation present there, as these cells are able to produce IFN- $\gamma$ and TNF- $\alpha$ in addition to IL-17, thus creating a pro-inflammatory microenvironment that is able to promote viral replication and weaken intestinal structural integrity. ${ }^{10,57}$ Alternatively, the accumulation of CCR $6{ }^{+} \mathrm{CD} 4{ }^{+}$ $\mathrm{T}$ cells could be a consequence of the high levels of inflammation present during pathogenic HIV/SIV infection, rather than the cause of it, since inflammation and microbial translocation increase CCL20 production by epithelial cells. ${ }^{47,48}$ In addition to epithelial cells, CCR $6{ }^{+} \mathrm{CD} 4{ }^{+} \mathrm{T}$ cells are also able to produce CCL20, ${ }^{24}$ which attracts more CCR ${ }^{+}$ $\mathrm{CD}^{+}$viral targets to the gut mucosa as well as CCR6expressing plasmacytoid dendritic cells (pDCs). These pDCs can subsequently recruit $\mathrm{CCR} 5^{+}$targets through their MIP-1a and MIP-1b production and produce high levels of Type-I IFNs. ${ }^{52}$ In fact, blocking CCL20 production using the inhibitor glycerol monolaurate was able to prevent acquisition of SIV in vaginally challenged $\mathrm{RMs} .{ }^{52}$ Thus, recruiting and accumulating CCR6 ${ }^{+} \mathrm{CD} 4{ }^{+} \mathrm{T}$ cells to the gut mucosa may be damaging to the host by accelerating recruitment of viral targets, which then expands the pool of virally infected cells, and, invariably, the viral reservoir. Indeed, CCR6 ${ }^{+} \mathrm{CXCR}^{+}{ }^{+} \mathrm{CD} 4{ }^{+} \mathrm{T}$ cells were recently shown to be enriched in integrated HIV DNA in long-term ART-suppressed HIV-infected individuals, when compared with other memory $\mathrm{CD} 4{ }^{+} \mathrm{T}$-cell subsets; ${ }^{58}$ thus, accumulating $\mathrm{CCR} 6{ }^{+} \mathrm{CD} 4{ }^{+} \mathrm{T}$ cells in the mucosa can damage the host due both to their own susceptibility to infection but also to their ability to persist and sustain the viral reservoir.

Apart from its functional role in coordinating the migration of CD4 ${ }^{+}$T cells, CCR6 also is used to phenotypically identify Th17 cells, most often in combination with CCR4 and CD161. ${ }^{36,37,40,41}$ In our study, the accumulation of CCR6 ${ }^{+}$ $\mathrm{CD} 161^{-}$and CCR6 ${ }^{+} \mathrm{CD} 161^{+} \mathrm{CD}^{+}{ }^{+}\left(\mathrm{CCR} 6^{+} \mathrm{CD} 4{ }^{+}\right) \mathrm{T}$ cells in the gut mucosa of SIV-infected RMs did not correspond to an 
increase in mucosal Th17 cells (data not shown), likely due to a combination of factors. First, it is possible that environmental factors promoting the polarization of Th17 cells are not present in this setting. The differentiation of Th17 cells requires a combination of cytokines, including IL- 6 , transforming growth factor- $\beta$ (TGF- $\beta$ ), and IL- $1 \beta$, and later IL-21 and IL-23 for their expansion and survival. ${ }^{59,60}$ Although some studies have demonstrated an upregulation of a number of Th17 polarization cytokines during HIV infection, including TGF- $\beta$, IL-6, and IL-23, ${ }^{61,62}$ other studies have found reduced production of IL-21 in the RB of SIV-infected RMs, which could impact the maintenance of $\mathrm{CCR}^{+}{ }^{+} \mathrm{CD} 4{ }^{+} \mathrm{T}$ cells as Th17 cells in the mucosa. ${ }^{30}$ Second, even if $\mathrm{CCR} 6{ }^{+} \mathrm{CD} 4{ }^{+} \mathrm{T}$ cells accumulated in the presence of Th17-polarizing cytokines, this subset may express lower levels of cytokine receptors on their surface, thus leaving them unable to receive the Th17-polarizing signals. While the expression levels of these receptors remains to be tested specifically on $\mathrm{CCR} 6{ }^{+} \mathrm{CD} 4{ }^{+} \mathrm{T}$ cells, both IL-6R and TGF- $\beta$ R levels are decreased on bulk CD4 ${ }^{+}$T cells during HIV and SIV infection, respectively. ${ }^{63,64}$ Finally, an upregulation of negative regulatory genes, such as PIAS3, SHP2, and SOCS3, may suppress the expression of IL-17 in these accumulated $\mathrm{CCR}^{+}{ }^{+} \mathrm{CD} 4{ }^{+} \mathrm{T}$ cells during SIV infection, as these genes are upregulated in bulk CD4 ${ }^{+}$T cells from SIV-infected RMs. ${ }^{65}$ Understanding how these mechanisms coordinate specifically within mucosal $\mathrm{CCR}^{+}{ }^{+} \mathrm{CD} 4{ }^{+} \mathrm{T}$ cells to suppress Th17 expression will be an important future question in elucidating their role in disease progression.

Along with identifying the redistribution of $\mathrm{CCR}^{+}{ }^{+} \mathrm{CD} 161^{-}$ and CCR6 ${ }^{+} \mathrm{CD} 161^{+} \mathrm{CD} 4{ }^{+}$T cells to the gut mucosa as a main mechanism for their loss from the blood of chronically infected individuals, we found that $\mathrm{CD} 161^{+} \mathrm{CCR}^{-} \mathrm{CD} 4{ }^{+} \mathrm{T}$ cells were depleted from all tissue compartments during SIV infection and harbored significantly higher levels of viral RNA. These results underline the heightened susceptibility of $\mathrm{CD}_{161}{ }^{+} \mathrm{CCR} 6^{-}$ $\mathrm{CD}^{+}{ }^{+} \mathrm{T}$ cells to SIV infection, which is likely facilitated by their high levels of CCR5 expression (Figure 2a, Supplementary Figure 3A). Although high levels of CXCR3 expression on $\mathrm{CD} 161^{+} \mathrm{CCR}^{-} \mathrm{CD}^{+}{ }^{+} \mathrm{T}$ cells (Supplementary Figure 4B) favor a Th1 phenotype and agree with their increased IFN- $\gamma$ production, their CXCR3 expression may also suggest their contribution to a subset of germinal center TFH cells that are preferentially infected in LN, given their high levels of cellassociated SIV RNA (Figure 6c). ${ }^{53}$ Indeed, higher levels of SIV RNA with comparable levels of SIV DNA would indicate increased transcriptional activity in the $\mathrm{CD} 161^{+} \mathrm{CCR}^{-} \mathrm{CD} 4{ }^{+}$ $\mathrm{T}$-cell subset in LN, as has been shown in TFH from $\mathrm{HIV}$-infected persons. ${ }^{66}$ We also found a loss of $\mathrm{CD} 161^{+} \mathrm{CD} 8{ }^{+} \mathrm{T}$ cells in the blood of SIV-infected RMs (Figure 3c). Circulating $\mathrm{CD} 161^{+} \mathrm{CD}^{+}$MAIT cells are similarly decreased from the blood of HIV-infected individuals, where their depletion has been proposed to result from increased activation-induced cell death following interaction with microbial products in mucosal sites. ${ }^{50}$

The preservation of $\mathrm{CD} 161^{+} \mathrm{CCR}^{-} \mathrm{CD} 4^{+} \mathrm{T}$ cells in the blood of SIV-infected natural host SMs supports a model where the infection and loss of these cells promotes disease progression. Indeed, elite controllers (ECs) also maintain their levels of circulating CD161 ${ }^{+} \mathrm{CD} 4{ }^{+}$T cells. ${ }^{67}$ Preservation of $\mathrm{CD} 161^{+} \mathrm{CCR}^{-}{ }^{-} \mathrm{CD} 4{ }^{+} \mathrm{T}$ cells in these two models is still compatible with viral infection being a key contributor to the depletion of this cell subset during progressive HIV/SIV infection. The ability of SMs to preserve CD161 ${ }^{+} \mathrm{CCR}^{-}$ $\mathrm{CD}^{+}{ }^{+} \mathrm{T}$ cells despite high levels of plasma viremia may result from their markedly lower levels of CCR 5 expression on CD ${ }^{+}$ $\mathrm{T}$ cells as compared with $\mathrm{RMs},{ }^{68,69}$ while preservation of $\mathrm{CD}_{161}{ }^{+} \mathrm{CD}^{+} \mathrm{T}$ cells in ECs may result from their significantly lower levels of HIV viremia when compared with normal progressors. $^{70}$

In conclusion, CCR6 and CD161-expressing CD4 ${ }^{+} \mathrm{T}$ cells are preferentially lost from the blood during pathogenic SIV infection in RMs, but their loss disrupts immune homeostasis by distinct mechanisms. Increased levels of the SIV co-receptor CCR5 likely contribute to the enriched viral targeting of $\mathrm{CD} 161^{+} \mathrm{CCR}^{-}{ }^{-} \mathrm{CD} 4{ }^{+} \mathrm{T}$ cells and their eventual depletion from multiple tissue compartments during chronic infection. On the other hand, $\mathrm{CCR}^{+}{ }^{+} \mathrm{CD} 161^{-}$and $\mathrm{CCR} 6{ }^{+} \mathrm{CD} 161^{+}$ $\mathrm{CD} 4{ }^{+} \mathrm{T}$ cells traffic from the blood to the gut mucosa during SIV infection, migrating towards increased levels of CCL20 produced there. Therefore, although the loss of CCR ${ }^{+} \mathrm{CD} 4^{+}$ $\mathrm{T}$ cells from circulation is indicative of disease progression, their accumulation in the gut mucosa further promotes damage to the host, as evidenced by their maintained levels in the mucosa of SIV-infected SMs. Moreover, ART is only able to partially reverse the redistribution and cell loss of these CD4 ${ }^{+}$ $\mathrm{T}$-cell subsets incurred during active viral replication, both in the blood of humans ${ }^{24}$ and in tissues here, thus underscoring the need for additional therapies that can restore CCR6 and CD161-expressing CD4 ${ }^{+}$T-cell homeostasis throughout the body and halt disease progression.

\section{METHODS}

Animals and SIV infection. For cross-sectional analysis, forty SIVnegative $(13.3 \pm 0.8$ years old) and 42 naturally SIV-infected (16.6 \pm 0.8 years old) SMs and 47 SIV-negative $(8.3 \pm 0.9$ years old $)$ and 31 SIVmac239-infected ( $6.8 \pm 0.7$ years old) RMs were included. In the SIV-infected animals, the average durations of infection were $8.91 \pm 0.90$ years for SMs, as estimated by the date of the first SIVpositive test, and $1.02 \pm 0.12$ years for RMs. For longitudinal analysis, six female RMs ( $8.6 \pm 0.6$ years old) were included, where all animals were $M a m u-\mathrm{B}^{\star} 08$ and $\mathrm{B}^{\star} 17$ negative. All 6 animals were infected intravenously with 300 TCID50 SIVmac239 (day 0). For cell sorting and analysis of cell-associated SIV DNA and RNA, ten chronically SIV-infected RMs were included, all of which had been infected intravenously with SIVmac239 (7 at a dose of 200 TCID50; 1 at 100 TCID50; and 2 at 3000 TCID50). The average duration of infection at the time of cell sorting (necropsy) was $517.0 \pm 34.4$ days. For longitudinal analysis of CCR6 ${ }^{+}$and $\mathrm{CD} 161^{+} \mathrm{CD} 4^{+}$T-cell frequencies during antiretroviral therapy (ART), eight RMs ( $4.2 \pm 0.2$ years old) were included. These RMs had been SIV-infected between 23 and 42 weeks (average of 31.5 weeks) before initiating a daily combination ART regimen consisting of a coformulated three-drug cocktail of tenofovir (PMPA), emtricitabine (FTC), and dolutegravir, administered with a daily subcutaneous injection. Two RMs were sacrificed within the first 4 weeks of ART due to rapid disease progression and weight loss. 
Sample collection and processing. Blood, lymph node (LN) and rectal (RB) biopsies were performed longitudinally from RMs as previously described. ${ }^{12}$ Blood samples were taken for a complete blood count and routine chemical analysis, and centrifuged within $1 \mathrm{~h}$ of phlebotomy for plasma separation. PBMCs were isolated from whole blood by density gradient centrifugation for both RMs and SMs. To obtain rectal biopsies, an anoscope was placed a short distance into the rectum for the collection of up to 20 pinch biopsies with biopsy forceps. $\mathrm{RB}$-derived lymphocytes were digested with $1 \mathrm{mg} \mathrm{ml}^{-1}$ collagenase for $2 \mathrm{~h}$ at $37^{\circ} \mathrm{C}$, and then passed through a $70 \mu \mathrm{m}$ cell strainer to remove residual tissue fragments. For LN biopsies, the skin over the axillary or inguinal region was clipped and surgically prepped before making an incision in the skin over the LN, which was exposed by blunt dissection and excised over clamps. LNs were then homogenized and passed through a $70 \mu \mathrm{m}$ cell strainer to isolate lymphocytes. All samples were processed, fixed (1\% paraformaldehyde), and analyzed within $24 \mathrm{~h}$ of collection. Chronically SIV-infected RMs were electively sacrificed and lymph nodes were collected from 3 sites-axillary, inguinal, and mesenteric, whose lymphocytes were pooled for FACS cell sorting.

Flow cytometric analysis. Fourteen-parameter flow cytometric analysis was performed on peripheral blood-, LN-, and RB-derived cells according to standard procedures using a panel of monoclonal antibodies that we and others have shown to be cross-reactive with SMs and RMs. ${ }^{12}$ The following antibodies were used at predetermined optimal concentrations: anti-CCR6-PE-Cy7 (clone 11A9), antiCCR5-PE and -APC (clone 3A9), anti-CD3-APC-Cy7 (clone SP34-2), anti-CD62L-FITC (clone SK11), anti-CD95-PE-Cy5 (clone DX2), anti-Ki-67-Alexa700 (clone B56), anti-IFN- $\gamma$-Alexa700 (clone B27), and anti-CXCR3-AlexaFluor 488 (clone 1C6/CXCR3) from BD Biosciences; anti-CD161-PE (clone HP-3G10) and anti-IL-17Alexa488 (clone eBio64DEC17) from eBioscience; anti-CD28-ECD (clone CD28.2) from Beckman Coulter; anti-CD4-BV421 (clone OKT4), anti-CD4-BV605 (clone OKT4), and anti-CD161-BV421 (clone HP-3G10) from Biolegend; anti-CD8-Qdot705 (clone 3B5) and Aqua Live/Dead amine dye-AmCyan from Invitrogen (Waltham, MA). Flow cytometric acquisition was performed on at least 100,000 $\mathrm{CD}^{+}{ }^{+} \mathrm{T}$ cells on an LSRII cytometer driven by the FACS DiVa software, or at least $10,000 \mathrm{CD} 3^{+} \mathrm{T}$ cells for rectal biopsy-derived cells. The data acquired were analyzed using FlowJo software (version 9.8.5; TreeStar, Ashland, OR).

Intracellular cytokine staining. Freshly isolated PBMCs and RBMCs were resuspended at a concentration of $3 \times 10^{6}$ cells per $\mathrm{ml}$ in RPMI 1640 medium supplemented with $10 \% \mathrm{FBS}, 100 \mathrm{IU} \mathrm{ml}^{-1}$ penicillin, and $100 \mu \mathrm{g} \mathrm{ml}^{-1}$ streptomycin. Stimulations were conducted for $4 \mathrm{~h}$ at $37^{\circ} \mathrm{C}$ in the presence of phorbol myristate acetate (PMA; $80 \mathrm{ng} \mathrm{ml}^{-1}$ ), ionomycin (500 $\mathrm{ng} \mathrm{ml}^{-1}$ ), brefeldin A, and GolgiStop. After $4 \mathrm{~h}$, cells were washed once with PBS to remove stimuli and stained with surface markers for CD3, CD4, CD8, CCR6, CD161, CD28, CD95, and CCR5 for $30 \mathrm{~min}$ at room temperature. Cells were then fixed with cytofix/ cytoperm (BD Pharmingen, San Diego, CA), washed, and stained intracellularly with antibodies specific for IL-17 and IFN- $\gamma$ for $1 \mathrm{~h}$ at room temperature. Following staining, cells were washed and fixed with PBS containing 1\% paraformaldehyde prior to acquiring on an LSRII cytometer.

CCL20 in situ hybridization and quantitative image analysis. In situ hybridization (ISH) was performed on formalin-fixed, paraffinembedded rectal biopsy tissues from the $6 \mathrm{RMs}$ monitored longitudinally. First, tissue sections were deparaffinized. Antigen retrieval was then performed by heating slides with alkaline antigen retrieval (Vector, Burlingame, CA) for $20 \mathrm{~min}$ in a microwave oven, transferring slides to 10 mm citrate buffer, $\mathrm{pH} 6.0$ until cool, and then washing twice in $2 \times$ SSC. A LAN probe was designed against CCL20 (Exiqon) and doubly labeled with Digoxigenin (dig) at each end (CCL20 probe: / 5digN/TGTGAAAGACGACAGCATTGA/3DIG_N/). The protocol was optimized for the detection of CCL20 and beta-actin (control
RNA) following common protocols. Briefly, tissue sections were covered with the hybridization buffer (50\% deionized formamide, $10 \%$ dextran sulfate, $1 \times$ Denhardt medium, $2 \mathrm{~mm}$ EDTA) containing $20 \mathrm{ng} \mathrm{ml}^{-1} \mathrm{CCL} 20$ probes and hybridized for $2 \mathrm{~h}$ at $30^{\circ} \mathrm{C}$. Slides were washed following hybridization: twice in $5 \times$ SSC for $5 \mathrm{~min}$, twice in $1 \mathrm{x}$ SSC for $5 \mathrm{~min}$, twice in $0.1 \times \mathrm{SSC}$ for $5 \mathrm{~min}$ - all at $37^{\circ} \mathrm{C}$ - and then once in $1 \times$ Tris-buffered saline at room temperature for $5 \mathrm{~min}$. Slides were blocked (Vector blocking solution) for $30 \mathrm{~min}$, before incubating with anti-DIG antibody (1:200, Roche) for $1 \mathrm{~h}$ at room temperature. After washing slides twice with $1 \times$ Tris-buffered saline for $10 \mathrm{~min}, \mathrm{BICP} /$ NBT was added to the slides and incubated for $20 \mathrm{~min}$ to allow for detection of the hybridized probe. DAPI (Sigma, St. Louis, MO) was used as a counter stain for detecting nuclei. Quantification of CCL20 mRNA ISH positive cells was performed on SIV-infected rectal biopsies at different time points during the course of infection and compared with pre-infection control samples from the same animal. CCL20 RNA ISH positive cells were counted in 10 high-power fields $(20 \times)$ for each biopsy. Images were collected using liquid crystal tunable filter multispectral imaging (Nuance Multispectral imaging system; Perkin-Elmer). Using the image analysis software Inform (Perkin-Elmer, Waltham, MA), we counted CCL20 positive cells and expressed this data as cells per nuclei counted (DAPI stained).

FACS cell sorting. Mononuclear cells isolated from the blood and pooled lymph nodes (axillary, inguinal and mesenteric) of chronically SIV-infected RMs were stained with anti-CD3, anti-CD4 (clone OKT4; BV650, Biolegend), anti-CD28, anti-CD95, anti-CCR6, and anti-CD161. Memory CD4 ${ }^{+} \mathrm{T}$ cells were then sorted based on their expression, or lack of expression, of CCR6 and CD161 using a FACS AriaII (BD Biosciences).

Quantification of cell-associated SIV DNA and RNA. Cell-associated SIV DNA and RNA were quantified for CCR6 and CD161-expressing memory CD $4{ }^{+}$T cells. Briefly, cellular DNA and RNA were extracted from sorted memory CD ${ }^{+}$T cells lysed in RLT Plus buffer (Qiagen, Germantown, MD) and isolated using the AllPrep DNA/RNA Mini Kit (Qiagen) per the manufacturer's instructions. Cell input ranged between 15,000 and 550,000 sorted cells from the PBMCs, and between 20,000 and 600,000 for LN. cDNA was synthesized from extracted RNA, and quantification of SIVmac gag DNA and cDNA was performed on samples using the QX100 Droplet Digital PCR system (BioRad). Total SIV DNA and RNA were quantified for these samples using SIVmac gag primers and probes, and normalized to the GAPDH gene. Data was analyzed using the Quantasoft analysis software 1.3.2.0 (Bio-rad, Hercules, CA).

Apoptosis analysis. Freshly isolated PBMCs from 8 healthy RMs $\left(2 \times 10^{6}\right.$ cells) were washed once with Annexin V buffer (BD Biosciences, San Jose, CA). PBMCs were then stained ex vivo with surface markers for CD3, CD4, CD8, CCR6, CD161, CD28, and CD95, as well as with Annexin V (APC; BD Biosciences) and Aqua Live/Dead amine dye-AmCyan (Invitrogen) for $30 \mathrm{~min}$ at room temperature. Following staining, cells were washed with Annexin V buffer and immediately acquired on an LSRII cytometer. $4 \times 10^{6}$ freshly isolated PBMCs from the same animals were also cultured for $24 \mathrm{~h}$ in complete RPMI media prior to performing Annexin V staining, as described above.

Statistics. Prior to implementation of any specific statistical analysis for each cross-sectional outcome, assumptions were assessed (i.e., normality and homogeneity of variance). If the underlying assumptions were met, a two-sided two-sample equal-variance $t$-test was performed to compare the differences in immunologic parameters between uninfected and SIV-infected animals, as well as between different $\mathrm{CD} 4^{+} \mathrm{T}$-cell subsets. If the assumptions were violated, the two-sample Mann-Whitney $U$-test was used to compare differences in outcomes between uninfected and SIV-infected animals. DNA and RNA measurements were excluded for samples in which $<15,000$ cells were sorted, as the assay was not 
sensitive enough to detect viral measurements consistently outside of this range. Two additional data points were excluded due to technical error. Cross-sectional analyses and comparisons of SIV DNA were conducted using GraphPad Prism 6.0 (San Diego, CA).

For our longitudinal investigations, repeated-measures analyses were performed for $\mathrm{CD}_{4}^{+}$and $\mathrm{CD} 8{ }^{+}$T-cell subsets with a means model via the SAS MIXED Procedure (version 9.4; SAS Institute, Cary, NC), which provides separate estimates of the means at each time point of the study. The model examined one predictor (time on study) with up to 13 categorical levels, and was fit separately for each anatomic location. A compound-symmetric variance-covariance form in repeated measurements was assumed for each outcome and robust estimates of the standard errors of parameters were used for performing statistical tests and constructing 95\% confidence intervals. The model-based means are unbiased with unbalanced and missing data, so long as the missing data was non-informative (missing at random, MAR). Four statistical tests were done within the framework of the mixed effects linear model for blood and rectal biopsy comparisons, and three for lymph node comparisons. All statistical tests were two-sided and unadjusted for multiple comparisons. A $P$ value $\leqslant 0.05$ was considered statistically significant for every statistical comparison.

To relate the decline of CCR $6{ }^{+} \mathrm{CD} 4{ }^{+} \mathrm{T}$-cell frequencies from the blood to their increase in RB, subset frequencies were ln transformed (log base e) prior to analysis by a mixed effects model. The model specified that $\ln \left(\% \mathrm{CCR} 6^{+}\right.$of $\left.\mathrm{CD} 4\right)$ in $\mathrm{RB}$ followed a linear regression over $\ln \left(\% \mathrm{CCR} 6^{+}\right.$of CD4) in blood, with a random intercept for each animal. The variance components included estimates of inter-animal and intra-animal variance.

Study approval. All animal experimentations were conducted according to guidelines established by the Animal Welfare Act and the $\mathrm{NIH}$ for housing and care of laboratory animals and performed in accordance with Institutional regulations after review and approval by the Institutional Animal Care and Usage Committees (IACUC; Permit number: 2001973) at the Yerkes National Primate Research Center (YNPRC). Anesthesia was administered prior to performing any procedure, and proper steps were taken to minimize the suffering of the animals in this study.

SUPPLEMENTARY MATERIAL is linked to the online version of the paper at http://www.nature.com/mi

\section{ACKNOWLEDGMENTS}

We thank Stephanie Ehnert, Christopher Souder, Tracy Meeker, Kay Lee Summerville, Research Services, and all the animal care and veterinary staff at the Yerkes National Primate Research Center; Kiran Gill at the Emory University Flow Cytometry Core; and Thomas Vanderford, Benton Lawson, and Melon T. Nega at the Emory Center for AIDS Research (CFAR) Virology and Molecular Biomarkers Core. We thank Nitasha Kumar for critical reading of the manuscript. We also thank Cecily Midkiff of Tulane University, as well as Ann Mayne and Dawn Little of Emory University for technical assistance. The SIVmac239 used to infect the RMs was kindly provided by Chris Miller. This work was supported by the NIAID, NIH under award numbers Al116379 and Al104278 (to M. Paiardini), ORIP/OD P51OD011132 (formerly NCRR P51RR000165, to the YNPRC), and P30AI50409 (to the Emory CFAR), as well as by amfAR 109109-57-RGRL (to M. Paiardini). The content of this publication does not necessarily reflect the views or policies of the Department of Health and Human Services, nor does mention of trade names, commercial products, or organizations imply endorsement by the U.S. Government.

\section{AUTHOR CONTRIBUTIONS}

C.S.M, L.M., and M.P. conceived the study; C.S.M., L.M., E.S.R., and R.I.I. performed cross-sectional analysis, longitudinal sample collection, processing, and FACS analysis; X.A. developed, optimized and analyzed in situ hybridization and subsequent output; C.S.M., B.C., R.I.I., and S.P. performed FACS cell sorting; S.H. and M.L. developed and performed droplet digital PCR analysis for SIVgag; C.S.M. and K.E. performed statistical analysis; C.S.M., X.A., K.E., and M.P. wrote the manuscript with inputs from all authors.

\section{DISCLOSURE}

The authors declared no conflict of interest.

c) 2017 Society for Mucosal Immunology

\section{REFERENCES}

1. Brenchley, J.M. et al. Microbial translocation is a cause of systemic immune activation in chronic HIV infection. Nat. Med. 12, 1365-1371 (2006).

2. Stein, T.P. et al. Weight loss, the gut and the inflammatory response in aids patients. Cytokine 9, 143-147 (1997).

3. Estes, J.D. et al. Damaged intestinal epithelial integrity linked to microbial translocation in pathogenic simian immunodeficiency virus infections. PLoS Pathog. 6, e1001052 (2010).

4. Brenchley, J.M. et al. CD4 ${ }^{+}$Tcell depletion during all stages of HIV disease occurs predominantly in the gastrointestinal tract. J. Exp. Med. 200, 749759 (2004).

5. Mehandru, S. et al. Primary HIV-1 infection is associated with preferential depletion of $\mathrm{CD} 4{ }^{+}$T lymphocytes from effector sites in the gastrointestinal tract. J. Exp. Med. 200, 761-770 (2004).

6. Veazey, R.S. et al. Gastrointestinal tract as a major site of CD4 ${ }^{+}{ }^{\top}$ cell depletion and viral replication in SIV infection. Science 280, 427-431 (1998).

7. Gordon, S.N. et al. Severe depletion of mucosal CD4 ${ }^{+}$Tcells in AIDS-free simian immunodeficiency virus-infected sooty mangabeys. J. Immunol. 179, 3026-3034 (2007)

8. Pandrea, IV et al. Acute loss of intestinal CD4 ${ }^{+}$T cells is not predictive of simian immunodeficiency virus virulence. J. Immunol. 179, 3035-3046 (2007).

9. Brenchley, J.M. et al. Differential Th17 CD4 T-cell depletion in pathogenic and nonpathogenic lentiviral infections. Blood 112, 2826-2835 (2008).

10. Cecchinato, V. et al. Altered balance between Th17 and Th1 cells at mucosal sites predicts AIDS progression in simian immunodeficiency virusinfected macaques. Mucosal. Immunol. 1, 279-288 (2008).

11. Favre, D. et al. Critical loss of the balance between Th17 and Tregulatory cell populations in pathogenic SIV infection. PLoS Pathog. 5, e1000295 (2009).

12. Pallikkuth, S. et al. Maintenance of intestinal Th17 cells and reduced microbial translocation in SIV-infected rhesus macaques treated with interleukin (IL)-21. PLoS Pathog 9, e1003471 (2013).

13. Raffatellu, M. et al. Simian immunodeficiency virus-induced mucosal interleukin-17 deficiency promotes Salmonella dissemination from the gut. Nat. Med. 14, 421-428 (2008).

14. Ivanov, II et al. The orphan nuclear receptor RORgammat directs the differentiation program of proinflammatory $\mathrm{IL}-17^{+}$Thelper cells. Cell 126, 1121-1133 (2006).

15. Dubin, P.J. \& Kolls, J.K. Th17 cytokines and mucosal immunity. Immunol. Rev. 226, 160-171 (2008).

16. Kao, C.Y. et al. IL-17 markedly up-regulates beta-defensin-2 expression in human airway epithelium via JAK and NF-kappaB signaling pathways. J. Immunol. 173, 3482-3491 (2004).

17. Kinugasa, T., Sakaguchi, T., Gu, X. \& Reinecker, H.C. Claudins regulate the intestinal barrier in response to immune mediators. Gastroenterology 118 , 1001-1011 (2000).

18. Klatt, N.R. et al. Loss of mucosal CD103 ${ }^{+} \mathrm{DCs}$ and $\mathrm{IL}-17^{+}$and $\mathrm{IL}-22^{+}$ lymphocytes is associated with mucosal damage in SIV infection. Mucosal Immunology 5, 646-657 (2012).

19. Liang, S.C. et al. Interleukin (IL)-22 and IL-17 are coexpressed by Th17 cells and cooperatively enhance expression of antimicrobial peptides. J. Exp. Med. 203, 2271-2279 (2006).

20. Gordon, S.N. et al. Disruption of intestinal CD4 ${ }^{+}$Tcell homeostasis is a key marker of systemic CD4 ${ }^{+}$T cell activation in HIV-infected individuals. J. Immunol. 185, 5169-5179 (2010).

21. Ryan, E.S. et al. Loss of function of intestinal IL-17 and IL-22 producing cells contributes to inflammation and viral persistence in SIV-infected rhesus macaques. PLoS Pathog. 12, e1005412 (2016). 
22. Alvarez, Y. et al. Preferential HIV infection of $\mathrm{CCR}^{+}{ }^{+}$Th17 cells is associated with higher levels of virus receptor expression and lack of CCR5 ligands. J. Virol. 87, 10843-10854 (2013).

23. El Hed, A. et al. Susceptibility of human Th17 cells to human immunodeficiency virus and their perturbation during infection. J. Infect. Dis. 201, 843-854 (2010).

24. Gosselin, A. et al. Peripheral blood CCR ${ }^{+} \mathrm{CCR}^{+}$and $\mathrm{CXCR} 3^{+} \mathrm{CCR} 6{ }^{+}$ CD4 ${ }^{+} \mathrm{T}$ cells are highly permissive to HIV-1 infection. J. Immunol. 184, 1604-1616 (2010).

25. Monteiro, P. et al. Memory CCR6 ${ }^{+} \mathrm{CD}^{+}{ }^{+}$Tcells are preferential targets for productive HIV type 1 infection regardless of their expression of integrin beta7. J. Immunol. 186, 4618-4630 (2011).

26. Rodriguez-Garcia, M., Barr, F.D., Crist, S.G., Fahey, J.V. \& Wira, C.R. Phenotype and susceptibility to HIV infection of CD4 ${ }^{+}$Th17 cells in the human female reproductive tract. Mucosal Immunol. 7, 1375-1385 (2014).

27. Stieh, D.J. et al. Th17 cells are preferentially infected very early after vaginal transmission of SIV in macaques. Cell Host Microbe 19, 529-540 (2016).

28. Persson, E.K. et al. IRF4 transcription-factor-dependent CD103 $\left({ }^{+}\right)$ $\mathrm{CD} 11 \mathrm{~b}\left({ }^{+}\right)$dendritic cells drive mucosal T helper 17 cell differentiation. Immunity 38, 958-969 (2013).

29. Iannello, A. et al. Dynamics and consequences of IL-21 production in HIVinfected individuals: a longitudinal and cross-sectional study. J. Immunol. 184, 114-126 (2010).

30. Micci, L. et al. Paucity of IL-21-producing CD4 $\left({ }^{+}\right)$T cells is associated with Th17 cell depletion in SIV infection of rhesus macaques. Blood 120, 3925-3935 (2012).

31. Korn, T. et al. IL-21 initiates an alternative pathway to induce proinflammatory $T(H) 17$ cells. Nature $448,484-487$ (2007).

32. Nurieva, R. et al. Essential autocrine regulation by IL-21 in the generation of inflammatory T cells. Nature 448, 480-483 (2007).

33. Yang, L. et al. IL-21 and TGF-beta are required for differentiation of human $\mathrm{T}(\mathrm{H}) 17$ cells. Nature 454, 350-352 (2008).

34. Micci, L. et al. Interleukin-21 combined with ART reduces inflammation and viral reservoir in SIV-infected macaques. J. Clin. Invest. 125, 4497-4513 (2015).

35. Mavigner, M. et al. Altered CD4 ${ }^{+}$Tcell homing to the gut impairs mucosal immune reconstitution in treated HIV-infected individuals. J Clin Invest 122, 62-69 (2012).

36. Acosta-Rodriguez, E.V. et al. Surface phenotype and antigenic specificity of human interleukin 17-producing Thelper memory cells. Nat. Immunol. 8 , 639-646 (2007).

37. Annunziato, F. et al. Phenotypic and functional features of human Th17 cells. J. Exp. Med. 204, 1849-1861 (2007).

38. Cook, D.N. et al. CCR6 mediates dendritic cell localization, lymphocyte homeostasis, and immune responses in mucosal tissue. Immunity $\mathbf{1 2}$, 495-503 (2000).

39. Yamazaki, T. et al. CCR6 regulates the migration of inflammatory and regulatory T cells. J. Immunol. 181, 8391-8401 (2008).

40. Cosmi, L. et al. Human interleukin 17-producing cells originate from a CD161 ${ }^{+} \mathrm{CD}^{+}{ }^{+}$T cell precursor. J. Exp. Med. 205, 1903-1916 (2008).

41. Kleinschek, M.A. et al. Circulating and gut-resident human Th17 cells express CD161 and promote intestinal inflammation. J. Exp. Med. 206, 525-534 (2009).

42. Billerbeck, E. et al. Analysis of CD161 expression on human CD8 ${ }^{+}$T cells defines a distinct functional subset with tissue-homing properties. Proc. Natl. Acad. Sci. U S A 107, 3006-3011 (2010).

43. Lanier, L.L., Chang, C. \& Phillips, J.H. Human NKR-P1A. A disulfide-linked homodimer of the C-type lectin superfamily expressed by a subset of NK and T lymphocytes. J. Immunol. 153, 2417-2428 (1994).

44. Lecureuil, C. et al. Trapping and apoptosis of novel subsets of memory $T$ lymphocytes expressing CCR6 in the spleen of HIV-infected patients. Blood 109, 3649-3657 (2007).

45. Loiseau, C. et al. CCR6- regulatory T cells blunt the restoration of gut Th17 cells along the CCR6-CCL2O axis in treated HIV-1-infected individuals. Mucosal Immunol. 9, 1137-1150 (2016).

46. Prendergast, A. et al. HIV-1 infection is characterized by profound depletion of $\mathrm{CD}_{161}{ }^{+}$Th17 cells and gradual decline in regulatory $\mathrm{T}$ cells. Aids 24, 491-502 (2010).

47. Ivanov, II et al. Induction of intestinal Th17 cells by segmented filamentous bacteria. Cell 139, 485-498 (2009).
48. Izadpanah, A., Dwinell, M.B., Eckmann, L., Varki, N.M. \& Kagnoff, M.F. Regulated MIP-3alpha/CCL20 production by human intestinal epithelium: mechanism for modulating mucosal immunity. Am. J. Physiol. Gastrointest. Liver Physiol. 280, G710-G719 (2001).

49. Sierro, F., Dubois, B., Coste, A., Kaiserlian, D., Kraehenbuhl, J.P. \& Sirard, J.C. Flagellin stimulation of intestinal epithelial cells triggers CCL20mediated migration of dendritic cells. Proc. Natl. Acad. Sci. USA 98, 13722-13727 (2001).

50. Cosgrove, C. et al. Early and nonreversible decrease of CD161 ${ }^{++} /$MAIT cells in HIV infection. Blood 121, 951-961 (2013).

51. Choi, Y.K., Fallert, B.A., Murphey-Corb, M.A. \& Reinhart, T.A. Simian immunodeficiency virus dramatically alters expression of homeostatic chemokines and dendritic cell markers during infection in vivo. Blood 101, 1684-1691 (2003).

52. Li, Q. et al. Glycerol monolaurate prevents mucosal SIV transmission. Nature 458, 1034-1038 (2009).

53. Velu, V. et al. Induction of Th1-Biased T Follicular Helper (Tfh) Cells in Lymphoid Tissues during Chronic Simian Immunodeficiency Virus Infection Defines Functionally Distinct Germinal Center Tfh Cells. J. Immunol. 197, 1832-1842 (2016).

54. Brenchley, J.M. Mucosal immunity in human and simian immunodeficiency lentivirus infections. Mucosal. Immunol. 6, 657-665 (2013).

55. Esplugues, E. et al. Control of $\mathrm{TH} 17$ cells occurs in the small intestine. Nature 475, 514-518 (2011).

56. Fontaine, J., Poudrier, J. \& Roger, M. Short communication: persistence of high blood levels of the chemokines CCL2, CCL19, and CCL20 during the course of HIV infection. AIDS Res. Hum. Retroviruses 27, 655-657 (2011).

57. Guillot-Delost, M. et al. Human CD90 identifies Th17/Tc17 T cell subsets that are depleted in HIV-infected patients. J Immunol 188, 981-991 (2012).

58. Khoury, G. et al. Persistence of integrated HIV DNA in CXCR3 ${ }^{+} \mathrm{CCR}^{+}$ memory $\mathrm{CD}^{+}{ }^{+} \mathrm{T}$ cells in HIV-infected individuals on antiretroviral therapy. Aids 30, 1511-1520 (2016).

59. Schmitt, N. \& Ueno, H. Regulation of human helper T cell subset differentiation by cytokines. Curr. Opin. Immunol. 34, 130-136 (2015).

60. Paiardini, M. Th17 cells in natural SIV hosts. Current Opinion HIV AIDS 5, 166-172 (2010).

61. Havlir, D.V. et al. Serum interleukin-6 (IL-6), IL-10, tumor necrosis factor (TNF) alpha, soluble type II TNF receptor, and transforming growth factor beta levels in human immunodeficiency virus type 1-infected individuals with Mycobacterium avium complex disease. J. Clin. Microbiol. 39, 298303 (2001).

62. Kekow, J., Wachsman, W., McCutchan, J.A., Cronin, M., Carson, D.A. \& Lotz, M. Transforming growth factor beta and noncytopathic mechanisms of immunodeficiency in human immunodeficiency virus infection. Proc. Natl. Acad. Sci. USA 87, 8321-8325 (1990).

63. George, J., Lewis, M.G., Renne, R. \& Mattapallil, J.J. Suppression of transforming growth factor beta receptor 2 and Smad5 is associated with high levels of microRNA miR-155 in the oral mucosa during chronic simian immunodeficiency virus infection. J. Virol. 89, 2972-2978 (2015).

64. Sun, C., Jiang, Y., Sun, L., Shang, H. \& Zhao, Y. The characteristics of Th1/Th2 cytokine receptors on monocytes in untreated patients of long term nonprogressor or chronic HIV infection. Curr. Mol. Med. 12, 1028-1039 (2012).

65. Bixler, S.L., Sandler, N.G., Douek, D.C. \& Mattapallil, J.J. Suppressed Th17 levels correlate with elevated PIAS3, SHP2, and SOCS3 expression in CD4 T cells during acute simian immunodeficiency virus infection. J. Virol. 87, 7093-7101 (2013).

66. Banga, R. et al. PD-1 and follicular helper T cells are responsible for persistent HIV-1 transcription in treated aviremic individuals. Nat. Med. 22, 754-761 (2016).

67. Gaardbo, J.C. et al. Immunoregulatory Tcells may be involved in preserving CD4 T cell counts in HIV-infected long-term nonprogressors and controllers. J. Acquir. Immune. Defic. Syndr. 65, 10-18 (2014).

68. Paiardini, M. et al. Low levels of SIV infection in sooty mangabey central memory $\mathrm{CD}(4)\left({ }^{+}\right) \mathrm{T}$ cells are associated with limited CCR5 expression. Nat. Med. 17, 830-836 (2011).

69. Pandrea, I. et al. Paucity of $\mathrm{CD} 4{ }^{+} \mathrm{CCR} 5^{+} \mathrm{T}$ cells is a typical feature of natural SIV hosts. Blood 109, 1069-1076 (2007).

70. Pereyra, F. et al. Persistent low-level viremia in HIV-1 elite controllers and relationship to immunologic parameters. J. Infect. Dis. 200, 984-990 (2009). 